\title{
Recent Strategies for Hydrogen Peroxide Production by Metal-Free Carbon Nitride Photocatalysts
}

\author{
André Torres-Pinto ${ }^{\circledR}$, Maria J. Sampaio, Cláudia G. Silva *® Joaquim L. Faria $₫$ and \\ Adrián M. T. Silva \\ Laboratory of Separation and Reaction Engineering-Laboratory of Catalysis and Materials (LSRE-LCM), \\ Faculdade de Engenharia, Universidade do Porto, Rua Roberto Frias, 4200-465 Porto, Portugal; \\ andretp@fe.up.pt (A.T.-P.); mjsampaio@fe.up.pt (M.J.S.); jlfaria@fe.up.pt (J.L.F.); adrian@fe.up.pt (A.M.T.S.) \\ * Correspondence: cgsilva@fe.up.pt; Tel.: +351-22-041-4874
}

Received: 23 October 2019; Accepted: 19 November 2019; Published: 26 November 2019

\begin{abstract}
Hydrogen peroxide $\left(\mathrm{H}_{2} \mathrm{O}_{2}\right)$ is a chemical which has gained wide importance in several industrial and research fields. Its mass production is mostly performed by the anthraquinone (AQ) oxidation reaction, leading to high energy consumption and significant generation of wastes. Other methods of synthesis found in the literature include the direct synthesis from oxygen and hydrogen. However, this $\mathrm{H}_{2} \mathrm{O}_{2}$ production process is prone to explosion hazard or undesirable by-product generation. With the growing demand of $\mathrm{H}_{2} \mathrm{O}_{2}$, the development of cleaner and economically viable processes has been under intense investigation. Heterogeneous photocatalysis for $\mathrm{H}_{2} \mathrm{O}_{2}$ production has appeared as a promising alternative since it requires only an optical semiconductor, water, oxygen, and ideally solar light irradiation. Moreover, employing a metal-free semiconductor minimizes possible toxicity consequences and reinforces the sustainability of the process. The most studied metal-free catalyst employed for $\mathrm{H}_{2} \mathrm{O}_{2}$ production is polymeric carbon nitride $(\mathrm{CN})$. Several chemical and physical modifications over $\mathrm{CN}$ have been investigated together with the assessment of different sacrificial agents and light sources. This review shows the recent developments on $\mathrm{CN}$ materials design for enhancing the synthesis of $\mathrm{H}_{2} \mathrm{O}_{2}$, along with the proposed mechanisms of $\mathrm{H}_{2} \mathrm{O}_{2}$ production. Finally, the direct in situ generation of $\mathrm{H}_{2} \mathrm{O}_{2}$, when dealing with the photocatalytic synthesis of added-value organic compounds and water treatment, is discussed.
\end{abstract}

Keywords: hydrogen peroxide; photocatalysis; carbon nitride; metal-free; oxygen reduction

\section{Introduction}

$\mathrm{H}_{2} \mathrm{O}_{2}$ is considered an environmentally friendly, active, and safe chemical in a broad range of applications, acting as a powerful oxidizing agent. $\mathrm{H}_{2} \mathrm{O}_{2}$ has been reported in environmental remediation, textile whitening, paper bleaching, chemical synthesis, cleansing of electronic materials, processing of metals, energy storage, and electric energy generation in fuel cells [1-3].

$\mathrm{H}_{2} \mathrm{O}_{2}$ is frequently present in the textile industry, reacting with the colouring matter during the bleaching process $[4,5]$. In organosynthesis, $\mathrm{H}_{2} \mathrm{O}_{2}$ has the capability to accelerate oxidation reactions, being exploited for the production of many fine and bulk chemicals [6]. Another application for $\mathrm{H}_{2} \mathrm{O}_{2}$ is in the field of fuel cells as it is a promising alternative energy carrier [7-10], due to its high energy density and ease/safety of storage (contrasting with $\mathrm{H}_{2}$ that presents some storage issues [11]). $\mathrm{H}_{2} \mathrm{O}_{2}$ can play a crucial role in the removal of pollutants from aqueous or gaseous effluents, being commonly combined with catalysts, ozone, or a light source. Wet peroxide oxidation (with and without catalysts), Fenton and photo-Fenton oxidations, and sono-, electro-, or photo-chemical reactions are some of the main processes where $\mathrm{H}_{2} \mathrm{O}_{2}$ is employed for water and wastewater treatment [12-19]. Particularly, 
$\mathrm{H}_{2} \mathrm{O}_{2}$ is widely used in photocatalytic water treatment because the addition or even in situ generation of $\mathrm{H}_{2} \mathrm{O}_{2}$ has been established as a promoter of the degradation of pollutants [20-32].

In response to an increasing $\mathrm{H}_{2} \mathrm{O}_{2}$ demand, different production processes have been developed and are currently operating at industry and laboratory scale [1]. However, many of these technologies often involve security issues regarding $\mathrm{H}_{2} / \mathrm{O}_{2}$ gas mixture, the use of organic solvents, metal catalysts, and the generation of undesirable by-products and solvent wastes [3]. Thus, to reduce these disadvantages, numerous approaches have been studied and developed for the synthesis of $\mathrm{H}_{2} \mathrm{O}_{2}$. These methods include: (i) chemical, sonochemical, and electrochemical processes, (ii) catalytic, and (iii) photocatalytic (metal-based or -free) systems.

$\mathrm{H}_{2} \mathrm{O}_{2}$ is produced mainly by the anthraquinone (AQ) route, commonly known as Riedl-Pfleiderer process [2,33-35]. This process is based on redox reactions [2,36,37], carried out in the presence of a mixture of organic solvents, e.g., ester/hydrocarbon or octanol/methyl-naphthalene. An alkylanthraquinone reacts with hydrogen, in the presence of a noble metal catalyst (e.g., Pt or Pd), and the corresponding alkylanthraquinol. The latter is oxidized under oxygenated conditions (air or $\mathrm{O}_{2}$ ), generating $\mathrm{H}_{2} \mathrm{O}_{2}$ and the former alkylanthraquinone. The quinol species can be further hydrogenated and oxygenated under the same conditions producing $\mathrm{H}_{2} \mathrm{O}_{2}$ and tetrahydroanthraquinone. Afterwards, $\mathrm{H}_{2} \mathrm{O}_{2}$ is recovered from the organic solution with water to obtain a $30 \% \mathrm{H}_{2} \mathrm{O}_{2}$ solution, which is then distilled under reduced pressure to remove impurities and increase its concentration. The anthraquinone process avoids implementing a $\mathrm{H}_{2} / \mathrm{O}_{2}$ gas mixture, which is known to be explosive, with this process being economically viable for large-scale production operations. However, there are still high operating costs associated with the acquisition of the raw materials, replacement of the catalysts, and the high energy requirement during the production procedure [2]. Another interesting technology for $\mathrm{H}_{2} \mathrm{O}_{2}$ generation consists on the application of sonochemistry which, by dissociation of oxygen and water, leads to the formation of $\mathrm{H}_{2} \mathrm{O}_{2}$ [38-41]. However, limitations of ultrasounds for chemical synthesis include long exposure time that can induce $\mathrm{H}_{2} \mathrm{O}_{2}$ decay and the difficulty in reactor design and process scale-up [42,43].

To reduce energy costs, the design of efficient and inexpensive catalytic processes has become imperative for the generation of $\mathrm{H}_{2} \mathrm{O}_{2}$. The use of metallic catalysts, such as $\mathrm{Pd}$ - and Au-based catalysts or metal oxides (e.g., $\mathrm{Al}_{2} \mathrm{O}_{3}$ or $\mathrm{TiO}_{2}$ ), has been thoroughly documented due to their high selectivity [44-56]. Although several catalytic technologies have been discussed in the literature, the focus of this review is on the application of heterogeneous photocatalysis for $\mathrm{H}_{2} \mathrm{O}_{2}$ production. Briefly, in heterogeneous photocatalysis, an optical semiconductor is irradiated by an appropriate light source for its activation, leading to the formation of photogenerated electron/hole pairs which, under certain conditions, have the ability to produce $\mathrm{H}_{2} \mathrm{O}_{2}$ [57]. Depending on the reaction medium, the electronic properties of specific optical semiconductors, and the wavelength and intensity of the radiation source, heterogeneous photocatalysis can be adjusted to different processes (e.g., degradation of aqueous contaminants and production of high-value chemicals, among others [58,59]). Furthermore, photocatalytic processes may be employed under ambient temperature and pressure conditions and can be activated by free and inexhaustible solar light, further reducing the energy costs in comparison with traditional thermally activated routes. In a careful look at the literature, it was possible to retrieve more than 11,000 scientific reports on the various approaches for $\mathrm{H}_{2} \mathrm{O}_{2}$ synthesis (source: Scopus database, October 2018). Although photocatalytic production of $\mathrm{H}_{2} \mathrm{O}_{2}$ can be considered a recent topic, in recent years, the number of publications has been increasing significantly, which indicates that this technology could be considered an interesting alternative to traditional routes.

Metal-metal oxide hybrid catalysts have also been widely studied as promising candidates in the context of photocatalytic production of $\mathrm{H}_{2} \mathrm{O}_{2}$, owing to their high chemical stability and low toxicity [60-63]. Among all the metal elements, $\mathrm{Ru}, \mathrm{Bi}, \mathrm{Co}$, and $\mathrm{Cd}$ are the most commonly combined with optical semiconductors, such as $\mathrm{TiO}_{2}$ (the standard photocatalyst) [36,64-71]. Despite their high efficiency for several photocatalytic applications, metal catalysts present viability problems and poor 
sustainability due to their high cost, difficulty of extraction from their ores, and possibility of leaching, which can contaminate the reaction medium and lead to the generation of hazardous wastes [72-75].

In this way, the development and optimization of metal-free structures as heterogeneous photocatalysts has been attracting wide interest. In the scope of metal-free photocatalytic $\mathrm{H}_{2} \mathrm{O}_{2}$ generation, the most employed material is polymeric carbon nitride $\left(\mathrm{g}-\mathrm{C}_{3} \mathrm{~N}_{4}\right.$, here denoted as $\left.\mathrm{CN}\right)$. Polymeric $\mathrm{CN}$ generally shows a relatively narrow band gap enabling visible light absorption, yet fast recombination of the photogenerated electron/hole pairs generally occurs. A sustainable process for photocatalytic $\mathrm{H}_{2} \mathrm{O}_{2}$ synthesis, besides requiring a visible-light activated metal-free material, requires the use of water instead of organic solvents (e.g., alcohols as sacrificial agents). $\mathrm{CN}$ can catalyse water splitting and selectively produce $\mathrm{H}_{2} \mathrm{O}_{2}$ under visible light irradiation though oxygen reduction [76-78].

Depending of the $\mathrm{CN}$ precursor and preparation method, the band potentials of $\mathrm{CN}$ (typically -1.12 and $1.58 \mathrm{eV}$, for the valence and conduction levels, respectively) are thermodynamically suitable for several applications, especially organic synthesis, $\mathrm{H}_{2}$ production, and pollutants degradation [79-83] Several reports have shown that pristine $\mathrm{CN}$ materials hold a small specific surface area and low chemisorption of oxygen, commonly leading to low photocatalytic efficiencies $[79,84]$. Thus, several modification strategies have been pursued to increase the efficiency of $\mathrm{CN}$-based photocatalysts, such as soft templating approaches, exfoliation, elemental doping, or heterojunction formation [79,85]. However, some authors report that, besides material engineering, photochemical considerations are a rather important issue to discuss since proper charge separation and transfer kinetics are needed for efficient $\mathrm{H}_{2} \mathrm{O}_{2}$ production [86,87].

Recently, Haider et al. [88] briefly summarized some studies concerning the synthesis of hybrid $\mathrm{CN}$-based photocatalysts for $\mathrm{H}_{2} \mathrm{O}_{2}$ production. Regardless of the several studies reported on the use of $\mathrm{CN}$ for $\mathrm{H}_{2} \mathrm{O}_{2}$ production by heterogeneous photocatalysis, a consolidated knowledge focused on the influence of both metal-free $\mathrm{CN}$ structure and the manipulation of the operating conditions for improving $\mathrm{H}_{2} \mathrm{O}_{2}$ productivity is still missing.

In the present review, the photocatalytic production of $\mathrm{H}_{2} \mathrm{O}_{2}$ using metal-free $\mathrm{CN}$ is explored. Herein, the influence of the catalyst tuning and process optimization is correlated and discussed. The capability of simultaneously producing $\mathrm{H}_{2} \mathrm{O}_{2}$ during the synthesis of value-added organic compounds and their ability to induce high photocatalytic degradation of organic pollutants present in waters is a crucial point taken into consideration in this study.

\section{2. $\mathrm{H}_{2} \mathrm{O}_{2}$ Production by Carbon Nitride Photocatalysts}

The photocatalytic production of $\mathrm{H}_{2} \mathrm{O}_{2}$ can occur through several pathways, which may differ depending on the use of metallic or non-metallic catalysts. The use of metal-based photocatalysts to generate $\mathrm{H}_{2} \mathrm{O}_{2}$ is well discussed in the literature [62,63,89-93]. However, using non-metals, such as $\mathrm{CN}$ materials, the reaction pathway for $\mathrm{H}_{2} \mathrm{O}_{2}$ generation is still under study. A general scheme is depicted in Figure 1, illustrating the main steps occurring after photoactivation of $\mathrm{CN}$ in the presence of molecular oxygen and water. After light absorption, the migration of electrons from the valence band $(\mathrm{VB})$ to the conduction band (CB) occurs. Then, electrons $\left(\mathrm{e}^{-}\right)$in the $\mathrm{CB}$ and photogenerated holes $\left(\mathrm{h}^{+}\right)$migrate to the surface of the photocatalyst and participate in reduction and oxidation reactions, respectively.

To improve $\mathrm{H}_{2} \mathrm{O}_{2}$ synthesis with photoactive $\mathrm{CN}$, it is necessary to understand the reactions that take place at the photocatalyst surface. The pathway for $\mathrm{H}_{2} \mathrm{O}_{2}$ synthesis using $\mathrm{CN}$ photocatalysts is generally ascribed to the capacity of this material to drive two-electron oxygen reduction. Figure 2 represents the photoactivation of $\mathrm{CN}$ with visible light and the mechanism for $\mathrm{H}_{2} \mathrm{O}_{2}$ production suggested by Shiraishi et al. [94]. The authors propose that the electron/hole pairs are localized in the 1, 4 and 2, 6 positions highlighted in Figure 2, with the negatively charged sites attracting oxygen and later reacting with the trapped protons in nearby $\mathrm{N}$ atoms. Then, a selected alcohol is used as sacrificial agent. Photoexcited electrons react with $\mathrm{O}_{2}$, leading to the formation of the 1,4-endoperoxide species, which results in the liberation of $\mathrm{H}_{2} \mathrm{O}_{2}$. At the same time, a proton donor (e.g., an alcohol or 
water) undergoes oxidation and yields protons that contribute to generating $\mathrm{H}_{2} \mathrm{O}_{2}$ [76]. The efficient formation of the endoperoxide species suppresses one- and four-electron reduction of $\mathrm{O}_{2}$ (Equation (1), (2), respectively), improving the selectivity of two-electron reduction of $\mathrm{O}_{2}$ (Equation (3)). However, $\mathrm{O}_{2}$ on pristine $\mathrm{CN}$ preferably undergoes reduction to $\mathrm{O}_{2}{ }^{\bullet-}$ via one-electron reduction (Equation (1)), while on modified $\mathrm{CN}$ materials with more surface defects, a more facile production of $\mathrm{H}_{2} \mathrm{O}_{2}$ is achieved (Equation (3)) [95].

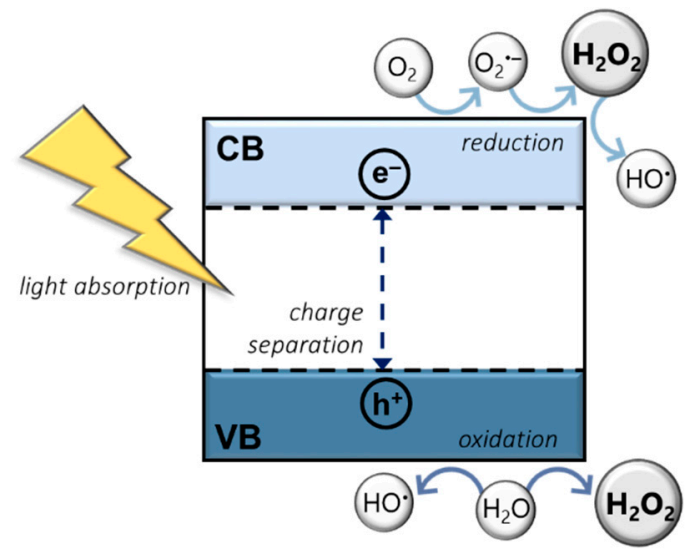

Figure 1. Photocatalytic activation and formation of reactive oxygen species in the presence of oxygen $\left(\mathrm{O}_{2}\right)$ and water $\left(\mathrm{H}_{2} \mathrm{O}\right) . \mathrm{H}_{2} \mathrm{O}_{2}=$ hydrogen peroxide; $\mathrm{O}_{2}{ }^{\bullet-}=$ superoxide radical; $\mathrm{HO} \mathrm{C}^{\bullet}=$ hydroxyl radical; $\mathrm{VB}=$ valence band; $\mathrm{CB}=$ conduction band $; \mathrm{e}^{-}=$electrons; $\mathrm{h}^{+}=$photogenerated holes.

$$
\begin{gathered}
\mathrm{O}_{2}+\mathrm{e}^{-} \rightarrow \mathrm{O}_{2}^{\bullet-} \\
\mathrm{O}_{2}+4 \mathrm{e}^{-}+4 \mathrm{H}^{+} \rightarrow 2 \mathrm{H}_{2} \mathrm{O} \\
\mathrm{O}_{2}+2 \mathrm{e}^{-}+2 \mathrm{H}^{+} \rightarrow \mathrm{H}_{2} \mathrm{O}_{2}
\end{gathered}
$$

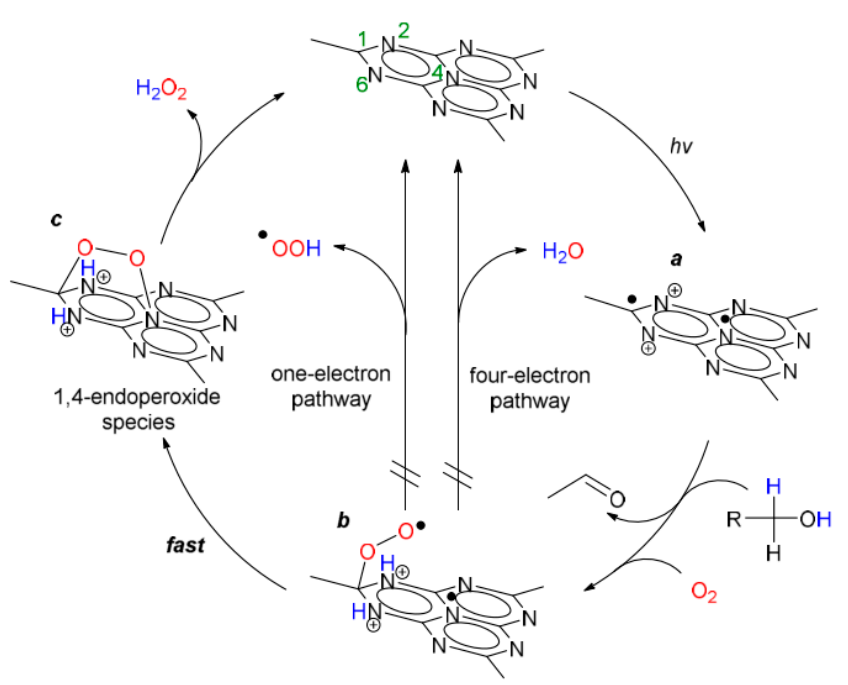

Figure 2. Proposed mechanism for selective formation of $\mathrm{H}_{2} \mathrm{O}_{2}$ on the photoactivated $\mathrm{CN}$ surface. Reprinted with permission from reference [94]. Copyright 2015 American Chemical Society.

Shiraishi et al. [76] reported Raman spectroscopy and electron spin resonance (ESR) studies that in their work, rationalizing the mechanism behind the selective two-electron reduction of $\mathrm{O}_{2}$ on photoexcited CN. After irradiation, the Raman spectrum of $\mathrm{CN}$ catalyst in an $\mathrm{O}_{2}$-saturated solution showed a new broad peak at $891 \mathrm{~cm}^{-1}$, ascribed to bond vibrations in the 1,4-endoperoxide species. 
Concerning the ESR analyses, products of one-electron reduction of $\mathrm{O}_{2}$ were not found, proving that $\mathrm{O}_{2}$ is being selectively reduced to $\mathrm{H}_{2} \mathrm{O}_{2}$ [76].

In another work, authors reported the formation of $\mathrm{H}_{2} \mathrm{O}_{2}$ by a two-step single-electron reduction of $\mathrm{O}_{2}$ (Equations (1) and (4)), via the reduction of $\mathrm{O}_{2}{ }^{\bullet-}$ (reduction product of $\mathrm{O}_{2}$ ) to $\mathrm{H}_{2} \mathrm{O}_{2}$ [96]. Additionally, under suitable conditions (i.e., with an appropriate $\mathrm{VB}$ energy), water oxidation may occur, generating $\mathrm{H}_{2} \mathrm{O}_{2}$ (Equation (5)) $[96,97] . \mathrm{H}_{2} \mathrm{O}_{2}$ can also evolve via the transformation of $\mathrm{HO}^{\bullet}$ formed from the hole-oxidation of $\mathrm{HO}^{-}$(Equation (6), (7)) [96]. These pathways enable the production of $\mathrm{H}_{2} \mathrm{O}_{2}$ by both oxidation and reduction routes (Figure 1). However, $\mathrm{H}_{2} \mathrm{O}_{2}$ production from water and $\mathrm{O}_{2}$ is hard to facilitate using the bulk $\mathrm{CN}$ photocatalyst, owing to the small thermodynamic driving force between the VB energy $(1.4 \mathrm{~V})$ and the water oxidation potential $(0.8 \mathrm{~V})$ [76,98-100].

$$
\begin{gathered}
\mathrm{O}_{2}^{\bullet-}+\mathrm{e}^{-}+2 \mathrm{H}^{+} \rightarrow \mathrm{H}_{2} \mathrm{O}_{2} \\
2 \mathrm{H}_{2} \mathrm{O}+2 \mathrm{~h}^{+} \rightarrow \mathrm{H}_{2} \mathrm{O}_{2}+2 \mathrm{H}^{+} \\
\mathrm{OH}^{-}+\mathrm{h}^{+} \rightarrow \mathrm{HO}^{\bullet} \\
2 \mathrm{HO}^{\bullet} \rightarrow \mathrm{H}_{2} \mathrm{O}_{2} \\
\mathrm{H}_{2} \mathrm{O}_{2}+\mathrm{e}^{-} \rightarrow \mathrm{OH}^{-}+\mathrm{HO}^{\bullet}
\end{gathered}
$$

$\mathrm{H}_{2} \mathrm{O}_{2}$ can drive the production of $\mathrm{HO}^{\bullet}$ in the presence of light (Equation (8)), depending on the radiation wavelength and catalyst employed $[20,22,23]$. The degradation of $\mathrm{H}_{2} \mathrm{O}_{2}$ to form $\mathrm{HO}$ radicals has a potential of $+0.39 \mathrm{~V} \mathrm{[101]}$ and, therefore, is favourable to occur on the $\mathrm{CB}$ of the semiconductor. In this way, the presence of $\mathrm{H}_{2} \mathrm{O}_{2}$ and photoactivated $\mathrm{CN}$ can generate $\mathrm{HO}$ radicals. These radicals are desired for several applications in environmental remediation, such as in water treatment, e.g., abatement of phenols [102], dyes [103], and antibiotics [104].

\section{Enhancing Photocatalytic Activity of Carbon Nitride}

In the following sections, metal-free strategies to modify $\mathrm{CN}$ will be overviewed and discussed to understand their influence on the efficiency and productivity of $\mathrm{H}_{2} \mathrm{O}_{2}$ photosynthesis. Several approaches can be found in the literature for improving the efficiency of this material, including thermal treatments, chemical substitutions with other carbon materials, or with specific organic molecules [105-107]. All these approaches are summarized in the following sections along with the correspondent experimental conditions of the photocatalytic tests and their ensuing results. The $\mathrm{H}_{2} \mathrm{O}_{2}$ productivity is depicted in terms of the highest amount produced after a respective irradiation time and moles of $\mathrm{H}_{2} \mathrm{O}_{2}$ per catalyst load and time, i.e., production rate $\left(\mu \mathrm{mol} \mathrm{g} \mathrm{cat}^{-1} \mathrm{~h}^{-1}\right)$.

Multiple articles have reported the preparation of $\mathrm{CN}$ using distinct precursors and their posterior application using different experimental conditions $[76,107,108]$. In Table 1 , the results in terms of $\mathrm{H}_{2} \mathrm{O}_{2}$ production using several neat $\mathrm{CN}$ materials are listed. Metal-free $\mathrm{CN}$ materials modified by several approaches are also shown in this table and discussed below.

Shiraishi et al. [76] reported the application of a metal-free $\mathrm{CN}$ material for $\mathrm{H}_{2} \mathrm{O}_{2}$ production using various alcohols for improving $\mathrm{H}_{2} \mathrm{O}_{2}$ selectivity. In this study, high $\mathrm{H}_{2} \mathrm{O}_{2}$ selectivity $(>90 \%)$ was achieved by using aqueous solutions of aliphatic or aromatic alcohols, namely ethanol, propan-2-ol, butan-2-ol, and benzyl alcohol. Concerning the proton donor, benzyl alcohol and propan-2-ol yielded the higher amounts of $\mathrm{H}_{2} \mathrm{O}_{2}$. Then, testing the system using solar irradiation with or without a light filter $(\lambda>420 \mathrm{~nm})$, higher selectivity for $\mathrm{H}_{2} \mathrm{O}_{2}$ formation is obtained when $\mathrm{CN}$ is activated by visible light rather than using the total spectrum range. This is due to ultraviolet light leading to the unwanted decomposition of $\mathrm{H}_{2} \mathrm{O}_{2}$.

Comparing the same matrix, light source, and gas but changing the precursor used in the catalyst synthesis, a much higher rate is achieved when using melamine [107] instead of cyanamide precursor [76]. 
The same group investigated the use of silica templates for changing the textural properties of $\mathrm{CN}$ [94]. The increase of surface defects leads to the formation of a large number of primary amines, which act as active sites for four-electron reduction of $\mathrm{O}_{2}$. A decrease on the selectivity towards $\mathrm{H}_{2} \mathrm{O}_{2}$ formation was observed in this system with the highest production rate of $188 \mu \mathrm{mol} \mathrm{g}_{\mathrm{cat}}{ }^{-1} \mathrm{~h}^{-1}$ and $60 \%$ selectivity.

\subsection{Surface Chemistry Modulation}

Li et al. [105] reported that $\mathrm{H}_{2} \mathrm{O}_{2}$ production can be improved up to 14 times in the absence of an organic electron scavenger in the presence of carbon-vacancies $(\mathrm{Cv})$. This study revealed that a post-treatment with argon led to the destruction of the crystallinity of $\mathrm{CN}$ and, therefore, produce defects, i.e., carbon vacancies (Figure 3). The $\mathrm{Cv}$ enhanced the trapping of the photogenerated electrons. Moreover, amino groups were formed and promoted electron transfer and changed the $\mathrm{H}_{2} \mathrm{O}_{2}$ production pathway from two-electron direct reduction of $\mathrm{O}_{2}$ to sequential one-electron reduction of $\mathrm{O}_{2}$ (Figure 3). In addition, it was also found that $\mathrm{Cv}$ decreased the band gap energy but did not interfere with the $\mathrm{CB}$ potential. This study showed that the chemisorption of $\mathrm{O}_{2}$ on the catalyst was enhanced with this modification. The effect of nitrogen vacancies (Nv) was also assessed, with the $\mathrm{H}_{2} \mathrm{O}_{2}$ production being much lower than using materials with $\mathrm{Cv}$. The highest $\mathrm{H}_{2} \mathrm{O}_{2}$ production rate obtained for $\mathrm{CN}-\mathrm{Cv}$ and $\mathrm{CN}-\mathrm{Nv}$ was 900 and $150 \mu \mathrm{mol} \mathrm{g}_{\mathrm{cat}^{-1}} \mathrm{~h}^{-1}$, respectively, under visible light $(\lambda>420 \mathrm{~nm})$ irradiation.
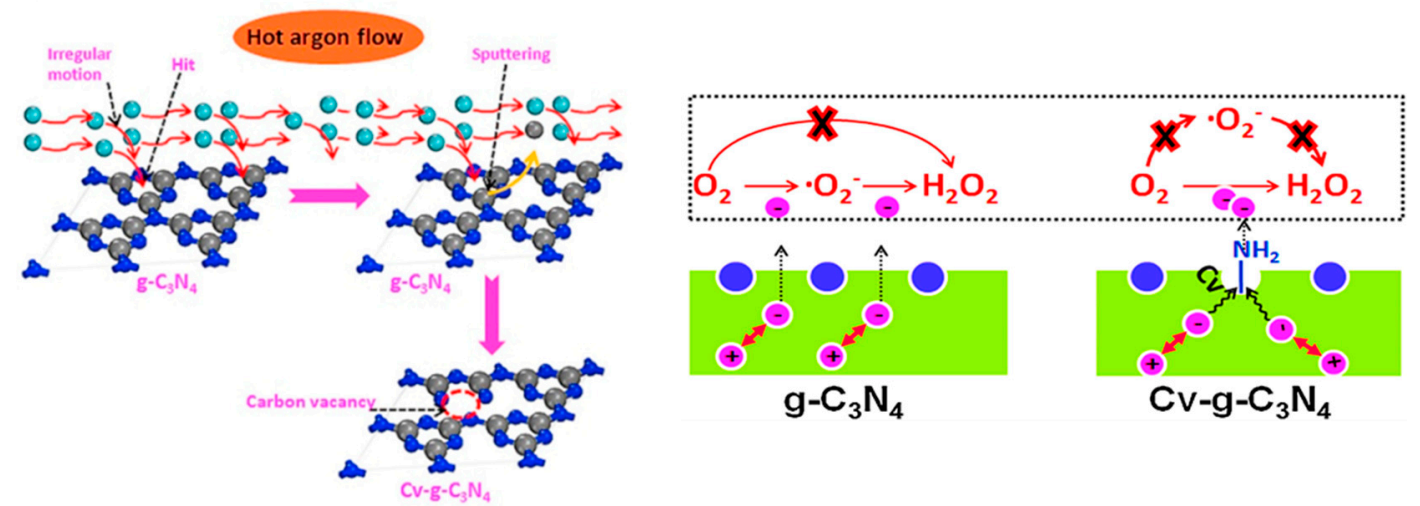

Figure 3. Formation of carbon vacancy on $\mathrm{CN}$ (left) and $\mathrm{H}_{2} \mathrm{O}_{2}$ formation pathway (right). Adapted with permission from reference [105]. Copyright 2016 Elsevier B.V.

In another study, the effect of the presence of nitrogen defects on a $\mathrm{CN}$ catalyst has been discussed in terms of their ability for reducing electron-hole recombination and improving the contact between the reactant and active sites on the catalyst surface [109].

Thermal post-treatment of bulk $\mathrm{CN}$ drives the cleavage between tri-s-triazine moieties forming nitride vacancies and increasing $C \equiv N$ groups on the matrix (Figure 4) [110]. This is accomplished by the incorporation of electron-deficient or $\pi$-conjugated monomers that falls for low bands energy potentials and inhibit the recombination. Moreover, the incorporation of strong electron acceptor groups can reduce the band gap energy and positively shift both CB and VB. The same authors investigated the impact of the saturated gas by testing the catalyst activity in the presence of $\mathrm{O}_{2}$, air, and $\mathrm{N}_{2}$ at the same conditions. It was observed that the $\mathrm{H}_{2} \mathrm{O}_{2}$ production rate was enhanced by saturating the suspensions with these gases, following the order $\mathrm{O}_{2}>$ air $>\mathrm{N}_{2}$. These results seems to indicate that most $\mathrm{H}_{2} \mathrm{O}_{2}$ production derives from $\mathrm{O}_{2}$ reduction with a small contribution from water oxidation.

Finally, another approach was performed by a plasma treatment with a power input of high voltage under $\mathrm{H}_{2}$ atmosphere with the main aim of the inclusion of $\mathrm{N}$ vacancies on the $\mathrm{CN}$ matrix [111]. These vacancies act as active sites for $\mathrm{O}_{2}$ adsorption and also have the capability to promote electron transfer, thus accelerating the reduction step. Furthermore, this catalyst suppressed the decomposition 
of $\mathrm{H}_{2} \mathrm{O}_{2}$, which resulted in a very high production rate of $2167 \mu \mathrm{mol} \mathrm{g}_{\mathrm{cat}}^{-1} \mathrm{~h}^{-1}$ in the presence of ethanol and pure $\mathrm{O}_{2}$.

\subsection{Functionalization}

The most recent studies found in the scope of metal-free photocatalytic $\mathrm{H}_{2} \mathrm{O}_{2}$ production consisted on the combination of $\mathrm{CN}$ with carbon, via doping or bonding with carbon nanotubes (CNT). Using C-doped $\mathrm{CN}$, a positive shift of the band potentials was found (Figure 5). This change on the VB accelerates water oxidation, and on the $\mathrm{CB}$ enhances oxygen reduction, improving $\mathrm{H}_{2} \mathrm{O}_{2}$ production owing to reduced kinetic barriers of the corresponding reactions. It was verified that $\mathrm{H}_{2} \mathrm{O}_{2}$ production is strongly dependent on the carbon content and the electronic structure of $\mathrm{CN}$. The synthesized material with highest $\mathrm{H}_{2} \mathrm{O}_{2}$ production simultaneously presented the highest formation and lowest decomposition rate constants, yielding a maximum $\mathrm{H}_{2} \mathrm{O}_{2}$ rate of $365 \mu \mathrm{mol} \mathrm{gat}^{-1} \mathrm{~h}^{-1}$ in a $5 \%$ propan-2-ol solution with $\mathrm{O}_{2}$ saturation [112]. This study strengthened the claim of the formation and decomposition of $\mathrm{H}_{2} \mathrm{O}_{2}$ being two competitive reactions, with the formation following a zero-order kinetics due to continuous $\mathrm{O}_{2}$ saturation, and the decomposition following a first-order kinetics.

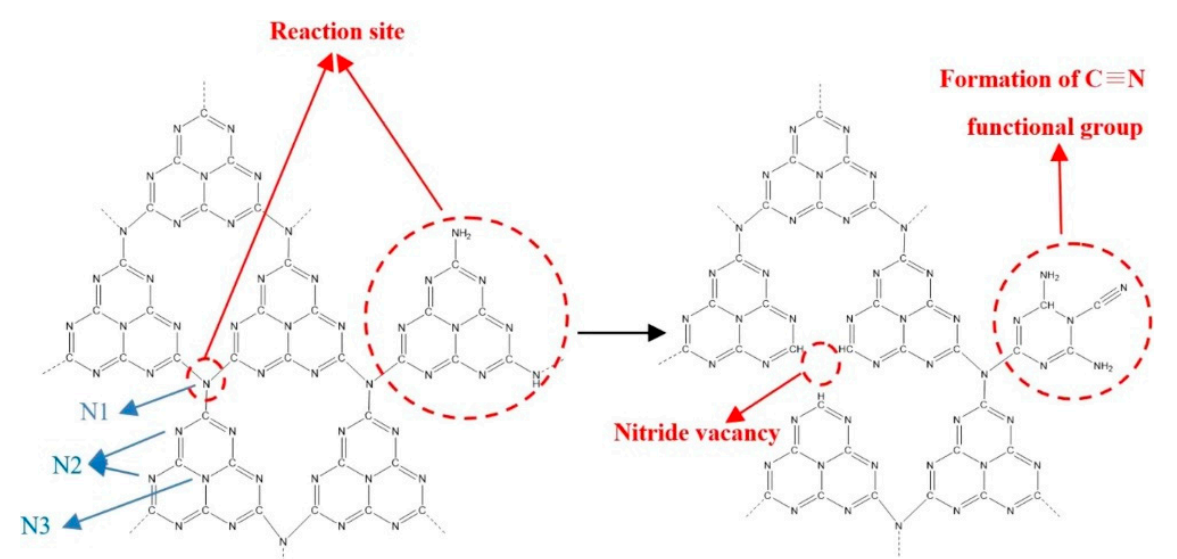

Figure 4. Nitrogen defects on $\mathrm{CN}$ matrix after thermal treatment. Adapted with permission from reference [110]. Copyright 2018 Elsevier B.V.

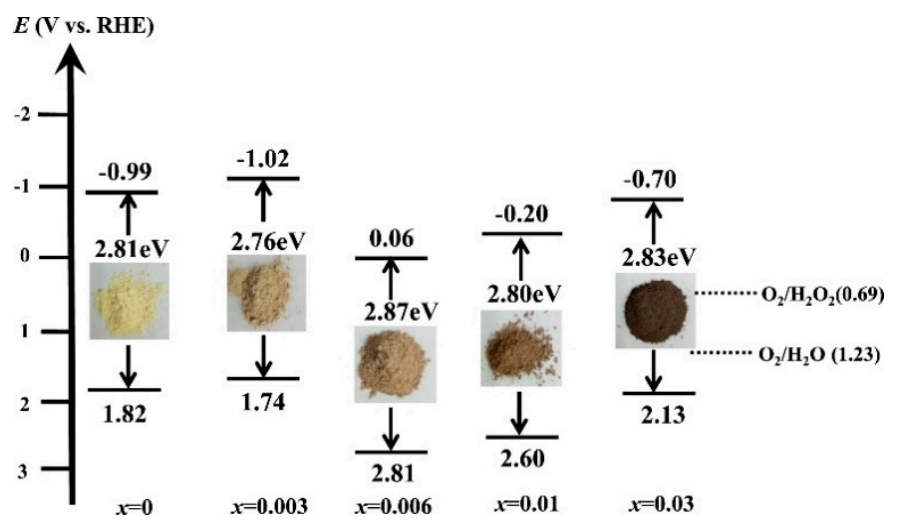

Figure 5. Energy levels of carbon (C)-doped CN ( $x$ denotes de carbon doping load). Reprinted with permission from reference [112]. Copyright 2018 Science Press and Dalian Institute of Chemical Physics, Chinese Academy of Sciences.

The covalent combination between $\mathrm{CNT}$ and $\mathrm{CN}$ (CN-CNT) promotes the sequential two-step pathway (Figure 2), using formic acid or methanol as electron donors. However, CN-CNT catalyses both water oxidation and $\mathrm{O}_{2}$ reduction, forming $\mathrm{H}_{2} \mathrm{O}_{2}$ without the need of an electron donor. This 
was proved by the presence of benzoquinone, which depresses $\mathrm{H}_{2} \mathrm{O}_{2}$ production by inhibiting the sequential two-step $\mathrm{O}_{2}$ reduction. This material reached a maximum production rate of $487 \mu \mathrm{mol}$ $\mathrm{g}_{\mathrm{cat}}{ }^{-1} \mathrm{~h}^{-1}$ using a 5:95 formic acid:water solution in $\mathrm{O}_{2}$-saturated conditions [106].

Another strategy to improve the $\mathrm{CN}$ photocatalytic activity is the anchoring of organic compounds, such as AQ. Moon et al. [113] showed that $\mathrm{H}_{2} \mathrm{O}_{2}$ production was dependent on the concentration of AQ and that, for higher AQ loads, there is a light block effect. When $A Q$ is physisorbed on $\mathrm{CN}$, the $\mathrm{H}_{2} \mathrm{O}_{2}$ production is improved. The authors explained the results based on the reutilization studies in which it was found that $\mathrm{AQ}$ remain at the $\mathrm{CN}$ surface, thus achieving a highly stable photocatalyst. $\mathrm{H}_{2} \mathrm{O}_{2}$ production was enhanced not only due to the higher $\mathrm{H}_{2} \mathrm{O}_{2}$ formation but also as a consequence of lower $\mathrm{H}_{2} \mathrm{O}_{2}$ decomposition. The authors also tested several AQ sources which lead to the functionalization with different groups. The material with $\mathrm{COOH}$ groups showed the highest formation and lowest decomposition rates, enabling continuous production over extended irradiation time in the presence of an electron donor. Furthermore, the apparent quantum yield profile resembles its absorption spectrum, meaning that efficient optical absorption and charge collection are achieved; however, with some useless recombination remains.

Benzene doping was tested by Kim et al. [114], achieving an $\mathrm{H}_{2} \mathrm{O}_{2}$ production rate of $300 \mu \mathrm{mol} \mathrm{g} \mathrm{cat}^{-1} \mathrm{~h}^{-1}$ that was obtained in $\mathrm{O}_{2}$-saturated conditions and using a $10 \%$ ethanol aqueous solution. The increase of photoactivity compared to the bulk material was mainly ascribed to the structure distortion (Figure 6), which was promoted by the substitution of the $\mathrm{N}$ atoms in the matrix by benzene with a much higher molecule size. In addition, the presence of benzene leads to an easier charge transfer and hinders the recombination of electron/hole pairs.

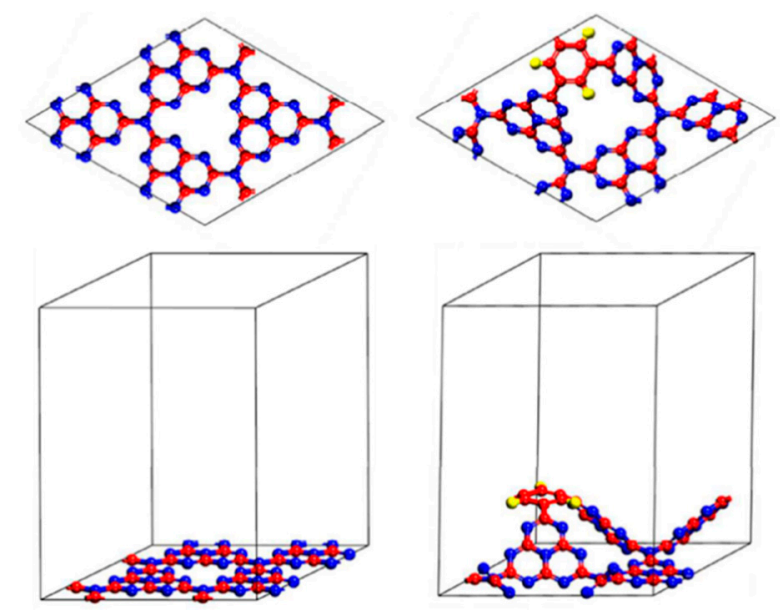

Figure 6. Top and side view of $\mathrm{CN}$ matrix before (left) and after distortion by benzene doping (right). Red, blue, and yellow represent carbon, nitrogen, and hydrogen atoms, respectively. Adapted with permission from reference [114]. Copyright 2017 American Chemical Society.

Several authors have reported doping $\mathrm{CN}$ with nitrogen, oxygen and phosphate as an efficient technique for increasing the efficiency for $\mathrm{H}_{2} \mathrm{O}_{2}$ production [115-117]. In the case of N-doping, it was described that it decreases $\mathrm{O}_{2}$ adsorption energy and enhances charge transfer [115]. Doping with oxygen promoted higher light absorption and efficient charge separation with a lower recombination rate [116]. The anchoring of phosphate on $\mathrm{CN}$ led to enhanced $\mathrm{O}_{2}$ adsorption, which was ascribed as the main reason for the increased $\mathrm{H}_{2} \mathrm{O}_{2}$ productivity [117].

\subsection{Construction of Heterostructures}

The combination of carbon materials, like fullerene $\left(\mathrm{C}_{60}\right)$, graphene oxide $(\mathrm{GO})$, and reduced graphene oxide (rGO), with $\mathrm{CN}$ have shown to promote a negative impact for $\mathrm{H}_{2} \mathrm{O}_{2}$ production owing to the higher affinity to one-electron $\mathrm{O}_{2}$ reduction route [108]. Even with $\mathrm{O}_{2}$ saturation and in the 
presence of a propan-2-ol solution (regarded as one of the best proton donors for this process [76]), the yield of $\mathrm{H}_{2} \mathrm{O}_{2}$ achieved with these hybrid materials was relatively low.

Aromatic diimides are n-type semiconductors with high electron mobility and stability. Therefore, their incorporation on the $\mathrm{CN}$ structure can lead to a positive shift on both VB and CB bands, owing to the high electron affinity [107].

Reports have been shown that pyromellitic diimide (PDI) units increase the rates of $\mathrm{H}_{2} \mathrm{O}_{2}$ formation as the valence band shifts promoting water oxidation to $\mathrm{O}_{2}$, facilitating $\mathrm{H}_{2} \mathrm{O}_{2}$ production (Figure 7). Shiraishi et al. [107] reported the use of a CN-PDI material using water and propan-2-ol as solvents. With this study, the authors obtained a much higher rate $\left(573 \mu \mathrm{mol} \mathrm{g}_{\mathrm{cat}}{ }^{-1} \mathrm{~h}^{-1}\right)$ for $\mathrm{H}_{2} \mathrm{O}_{2}$ production when the alcohol was present, due its capacity of acting as a strong proton donor [107]. In another work, the CN material was modified with biphenyl diimide (BDI) [77], and the effect of polymerization temperature was evaluated. The authors found an optimal temperature of $653 \mathrm{~K}$, which yielded $6.8 \mu \mathrm{mol}$ of $\mathrm{H}_{2} \mathrm{O}_{2}$ after $24 \mathrm{~h}$ of irradiation corresponding to a rate of $5.7 \mu \mathrm{mol} \mathrm{g} \mathrm{cat}^{-1} \mathrm{~h}^{-1}$. By increasing the polymerization temperature, the authors found a significant catalyst weight loss, followed by a decrease on the photocatalytic activity of the resulting materials. Moreover, the amount of BDI on the $\mathrm{CN}$ was studied, and among all the resulting materials, the best photocatalytic activity was achieved with a molar ratio of 50\% BDI in the catalyst, yielding $41 \mu \mathrm{mol}$ after $48 \mathrm{~h}$ of irradiation and a $9.7 \mu \mathrm{mol} \mathrm{g} \mathrm{cat}^{-1} \mathrm{~h}^{-1}$ rate. According to the calculated apparent quantum yield, BDI doping is more effective than PDI. BDI doping leads to a positive shift on the $\mathrm{VB}$ and $\mathrm{CB}$, enabling water oxidation and promoting $\mathrm{H}_{2} \mathrm{O}_{2}$ formation (Figure 7). Additionally, ab initio calculations suggest that there is a significant spatial charge separation $\left(\mathrm{h}^{+}\right.$in BDI and $\mathrm{e}^{-}$on melem; on PDI both $\mathrm{h}^{+}$and $\mathrm{e}^{-}$are on melem) which hinders their recombination improving $\mathrm{H}_{2} \mathrm{O}_{2}$ formation.

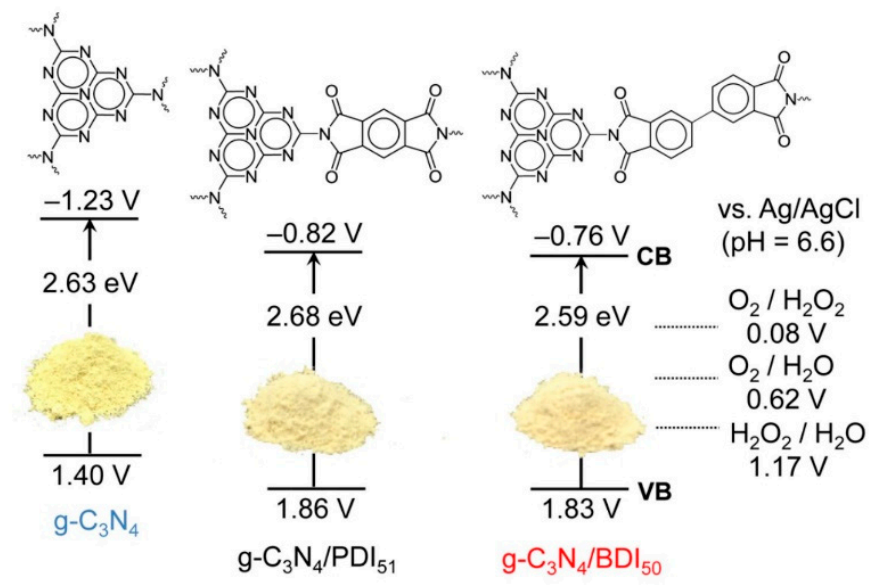

Figure 7. Electronic structure of different catalysts. Reprinted with permission from reference [77]. Copyright 2016 American Chemical Society. PDI = pyromellitic diimide; BDI = biphenyl diimide.

The photoactivity of catalysts, such as $\mathrm{CN}$, which are $\pi$-conjugated semiconductors, depends on the density and mobility of the photoformed charge carriers [118]. The same authors that used PDI also reported the combination of $\mathrm{CN}$ with mellitic triimide (MTI) [78]. The incorporation of MTI units and the subsequent stacking of melem layers can lead to efficient inter and intralayer charge transfer. Therefore, the CN-MTI catalyst showed improvements on the conductivity and charge transport, as well as a higher photoactivity, compared with the pristine $\mathrm{CN}$ towards $\mathrm{H}_{2} \mathrm{O}_{2}$ production.

PDI-, BDI-, and MTI-modified CN has also been combined with reduced graphene oxide (rGO). In general, rGO has the ability to trap photogenerated electrons from the $\mathrm{CB}$ of the CN-PDI material, acting as active sites for the two-electron reduction of $\mathrm{O}_{2}$. On the other hand, $\mathrm{CN}-\mathrm{PDI}-\mathrm{rGO}$ photocatalyst promoted slight decomposition of $\mathrm{H}_{2} \mathrm{O}_{2}$. However, using a physical mixture of CN-PDI and rGO, no significant effect was observed, which can be ascribed to the low interaction between CN-PDI and rGO materials [119]. 
Structures of $\mathrm{CN}$ coupled with boron nitride $(\mathrm{BN})$ were prepared to further enhance electron transfer $[120,121]$. The composite made with BN quantum dots favours the acceleration of charge transfer and the decrease of recombination [120]. The material with $\mathrm{BN}$ nanosheets resulted in an elevated production ( $1400 \mu \mathrm{mol} \mathrm{g}_{\mathrm{cat}}{ }^{-1} \mathrm{~h}^{-1}$ ) since the authors managed to decrease $\mathrm{H}_{2} \mathrm{O}_{2}$ decomposition while maintaining very high formation rates [121]. The addition of $\mathrm{BN}$ seems to promote the separation of holes hindering recombination. Kofuji et al. have explored the combination of a CN-PDI material with BN [122]. The photogenerated holes in the VB on the CN/PDI moiety move to the VB of BN leading to their entrapment, which enhances charge separation and promotes $\mathrm{H}_{2} \mathrm{O}_{2}$ production. Moreover, addition of rGO further inhibits the recombination of electrons and holes. The material consisting of CN-PDI combined with both BN and rGO resulted in the highest $\mathrm{H}_{2} \mathrm{O}_{2}$ production rates due to promoting both water oxidation and oxygen reduction (Figure 8), while increasing the charge transfer. Moreover, these studies also supported the impact of the presence of an alcohol as proton donor. The use of propan-2-ol as solvent increased the $\mathrm{H}_{2} \mathrm{O}_{2}$ production rate by a factor of 50, comparing with water.

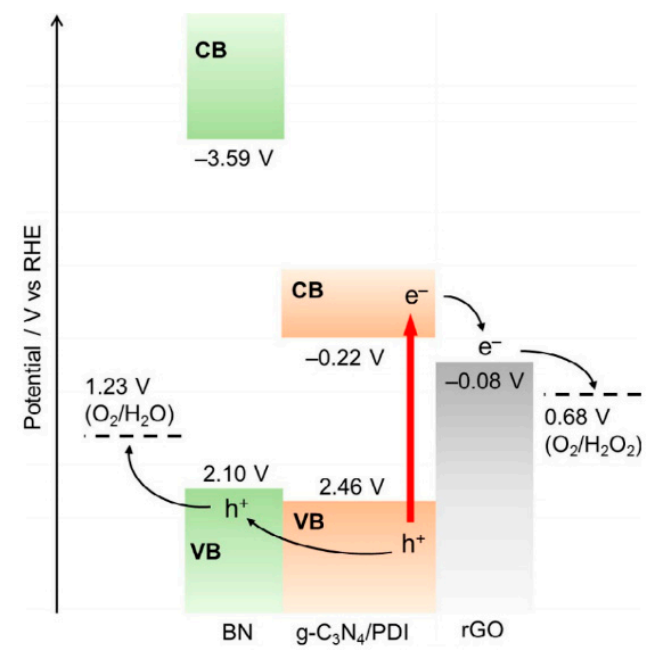

Figure 8. Energy diagram of the CN-PDI-reduced graphene oxide (rGO)- boron nitride (BN) catalyst. Reprinted with permission from reference [122]. Copyright 2018 Wiley-VCH Verlag GmbH \& Co.

KGaA, Weinheim, Germany.

Wang et al. [96] investigated the use of perylene imide (PI), to create a Z-scheme heterojunction with $\mathrm{CN}$ nanosheets for enhancing the oxidative power of photogenerated holes [123]. The CN-PI structures led to higher $\mathrm{H}_{2} \mathrm{O}_{2}$ production; however, for excessive PI amounts, light absorption by the nanosheets was compromised. PI seems to favour the separation of charge carriers and leads to faster interfacial charge transfer (Figure 9). The addition of PI changes the production of $\mathrm{H}_{2} \mathrm{O}_{2}$ from a direct two-electron oxygen reduction to a two-channel pathway (Equations (3) and (4)). Moreover, the presence of PI inhibits the subsequent decomposition of $\mathrm{H}_{2} \mathrm{O}_{2}$ [96]. 
Table 1. Metal-free $\mathrm{CN}$-based materials, experimental conditions, and respective photocatalytic results.

\begin{tabular}{|c|c|c|c|c|c|}
\hline \multirow[b]{2}{*}{ Modification on CN } & \multirow[b]{2}{*}{ Preparation Method } & \multirow[b]{2}{*}{ Experimental Conditions } & \multicolumn{2}{|l|}{ Photocatalytic Results } & \multirow[b]{2}{*}{ Ref. } \\
\hline & & & $\mathrm{H}_{2} \mathrm{O}_{2}$ Generated $(\mu \mathrm{mol})$ & $\begin{array}{l}\text { Production Rate }(\mu \mathrm{mol} \\
\left.\mathrm{g}_{\mathrm{cat}^{-1}} \mathrm{~h}^{-1}\right)\end{array}$ & \\
\hline None & $\begin{array}{l}\text { Thermal polymerization of cyanamide under } \mathrm{N}_{2} \\
\text { atmosphere }\end{array}$ & $\begin{array}{l}\text { 9/1 (v/v) propan-2-ol/water }(5 \mathrm{~mL}) ; 4 \mathrm{~g} \mathrm{~L}^{-1} ; 2000 \mathrm{~W} \text { Xe lamp }(\lambda> \\
420 \mathrm{~nm}) ; \mathrm{O}_{2}\end{array}$ & $60 \mu \mathrm{mol}(24 \mathrm{~h})$ & 125 & [76] \\
\hline None & $\begin{array}{l}\text { Thermal polymerization of cyanamide under } \mathrm{N}_{2} \\
\text { atmosphere }\end{array}$ & $\begin{array}{l}\text { 9/1 (v/v) benzyl alcohol/water matrix }(5 \mathrm{~mL}) ; 4 \mathrm{~g} \mathrm{~L}^{-1} ; 2000 \mathrm{~W} \mathrm{Xe} \\
\text { lamp }(\lambda>420 \mathrm{~nm}) ; \mathrm{O}_{2}\end{array}$ & $109 \mu \mathrm{mol}(24 \mathrm{~h})$ & 227 & [76] \\
\hline None & $\begin{array}{l}\text { Thermal polymerization of cyanamide under } \mathrm{N}_{2} \\
\text { atmosphere }\end{array}$ & $\begin{array}{l}\text { 9/1 (v/v) ethanol/water }(5 \mathrm{~mL}) ; 4 \mathrm{~g} \mathrm{~L}^{-1} ; 2000 \mathrm{~W} \text { Xe lamp }(\lambda>420 \\
\mathrm{nm}) ; \mathrm{O}_{2}\end{array}$ & $30 \mu \mathrm{mol}(24 \mathrm{~h})$ & 63 & [76] \\
\hline None & $\begin{array}{l}\text { Thermal polymerization of cyanamide under } \mathrm{N}_{2} \\
\text { atmosphere }\end{array}$ & $\begin{array}{l}9 / 1(v / v) \text { butan-1-ol/water }(5 \mathrm{~mL}) ; 4 \mathrm{~g} \mathrm{~L}^{-1} ; 2000 \mathrm{~W} \text { Xe lamp }(\lambda> \\
420 \mathrm{~nm}) ; \mathrm{O}_{2}\end{array}$ & $18 \mu \mathrm{mol}(24 \mathrm{~h})$ & 38 & [76] \\
\hline None & $\begin{array}{l}\text { Thermal polymerization of cyanamide under } \mathrm{N}_{2} \\
\text { atmosphere }\end{array}$ & $\begin{array}{l}\text { 9/1 (v/o) propan-1-ol/water }(5 \mathrm{~mL}) ; 4 \mathrm{~g} \mathrm{~L}^{-1} ; 2000 \mathrm{~W} \text { Xe lamp }(\lambda \\
>420 \mathrm{~nm}) ; \mathrm{O}_{2}\end{array}$ & $6.3 \mu \mathrm{mol}(24 \mathrm{~h})$ & 13 & [76] \\
\hline None & $\begin{array}{l}\text { Thermal polymerization of cyanamide under } \mathrm{N}_{2} \\
\text { atmosphere }\end{array}$ & 9/1 (v/v) propan-2-ol/water $(5 \mathrm{~mL}) ; 4 \mathrm{~g} \mathrm{~L}^{-1}$; sunlight; $\mathrm{O}_{2}$ & $120 \mu \mathrm{mol}(9 \mathrm{~h})$ & 667 & [76] \\
\hline None & $\begin{array}{l}\text { Thermal polymerization of cyanamide under } \mathrm{N}_{2} \\
\text { atmosphere }\end{array}$ & $\begin{array}{l}\text { 9/1 (v/v) propan-2-ol/water }(5 \mathrm{~mL}) ; 4 \mathrm{~g} \mathrm{~L}^{-1} \text {; sunlight }(\lambda>420 \\
\mathrm{nm}) ; \mathrm{O}_{2}\end{array}$ & $70 \mu \mathrm{mol}(9 \mathrm{~h})$ & 389 & [76] \\
\hline None & Thermal polymerization of melamine & $\begin{array}{l}\text { 9/1 (v/v) propan-2-ol/water }(30 \mathrm{~mL}) ; 1.7 \mathrm{~g} \mathrm{~L}^{-1} ; 2000 \mathrm{~W} \text { Xe lamp } \\
(\lambda>420 \mathrm{~nm}) ; \mathrm{O}_{2}\end{array}$ & $148 \mu \mathrm{mol}(6 \mathrm{~h})$ & 493 & [107] \\
\hline Adding surface defects & $\begin{array}{l}\text { Silica-templated thermal polymerization of } \\
\text { cyanamide under } \mathrm{N}_{2} \text { atmosphere }\end{array}$ & $\begin{array}{l}\text { 9/1 (v/v) ethanol/water }(5 \mathrm{~mL}) ; 4 \mathrm{~g} \mathrm{~L}^{-1} ; 2000 \mathrm{~W} \text { Xe lamp }(\lambda>420 \\
\mathrm{nm}) ; \mathrm{O}_{2}\end{array}$ & $90 \mu \mathrm{mol}(24 \mathrm{~h})$ & 188 & [94] \\
\hline Adding C vacancies & $\begin{array}{l}\text { Thermal polymerization of melamine and further } \\
\text { treatment under Ar atmosphere }\end{array}$ & water (100 mL); $1.0 \mathrm{~g} \mathrm{~L}^{-1} ; 300 \mathrm{~W}$ Xe lamp $(\lambda>420 \mathrm{~nm}) ; \mathrm{O}_{2}$ & $9 \mu \mathrm{mol}(1 \mathrm{~h})$ & 90 & [105] \\
\hline Adding $\mathrm{N}$ vacancies & $\begin{array}{l}\text { Thermal polymerization of melamine and further } \\
\text { treatment under } \mathrm{H}_{2} \text { atmosphere }\end{array}$ & water $(100 \mathrm{~mL}) ; 1.0 \mathrm{~g} \mathrm{~L}^{-1} ; 300 \mathrm{~W}$ Xe lamp $(\lambda>420 \mathrm{~nm}) ; \mathrm{O}_{2}$ & $1.5 \mu \mathrm{mol}(1 \mathrm{~h})$ & 15 & [105] \\
\hline Adding $\mathrm{N}$ vacancies & $\begin{array}{l}\text { Thermal polymerization of dicyandiamide and } \\
\text { photo-assisted post-treatment with hydrazine }\end{array}$ & $\begin{array}{l}20 \% \text { (v) propan-2-ol/water }(60 \mathrm{~mL}) ; 0.83 \mathrm{~g} \mathrm{~L}^{-1} ; \text { solar simulator } \\
(\lambda>420 \mathrm{~nm}) ; \mathrm{O}_{2}\end{array}$ & $12.1 \mu \mathrm{mol}(2.5 \mathrm{~h})$ & 97 & [109] \\
\hline Adding $\mathrm{N}$ vacancies & $\begin{array}{l}\text { Thermal polymerization of melamine and further } \\
\text { calcinated with sodium borohydride }\end{array}$ & water $(100 \mathrm{~mL}) ; 1.0 \mathrm{~g} \mathrm{~L}^{-1} ; 300 \mathrm{~W}$ Xe lamp $(\lambda \geq 420 \mathrm{~nm}) ; \mathrm{O}_{2}$ & $30.0 \mu \mathrm{mol}(1 \mathrm{~h})$ & 300 & [110] \\
\hline Adding $\mathrm{N}$ vacancies & $\begin{array}{l}\text { Thermal polymerization of melamine and further } \\
\text { calcinated with sodium borohydride }\end{array}$ & water (100 mL); $1.0 \mathrm{~g} \mathrm{~L}^{-1} ; 300 \mathrm{~W}$ Xe lamp ( $\left.\lambda \geq 400 \mathrm{~nm}\right)$; air & $17.0 \mu \mathrm{mol}(1 \mathrm{~h})$ & 170 & [110] \\
\hline Adding $\mathrm{N}$ vacancies & $\begin{array}{l}\text { Thermal polymerization of melamine and further } \\
\text { calcinated with sodium borohydride }\end{array}$ & water $(100 \mathrm{~mL}) ; 1.0 \mathrm{~g} \mathrm{~L}^{-1} ; 300 \mathrm{~W}$ Xe lamp $(\lambda \geq 400 \mathrm{~nm}) ; \mathrm{N}_{2}$ & $2.5 \mu \mathrm{mol}(1 \mathrm{~h})$ & 25 & [110] \\
\hline Adding $\mathrm{N}$ vacancies & $\begin{array}{l}\text { Thermal polymerization of melamine and } \mathrm{H}_{2} \text { plasma } \\
\text { treatment }\end{array}$ & $\begin{array}{l}50 \%(\mathrm{v}) \text { ethanol/water }(200 \mathrm{~mL}) ; 1.0 \mathrm{~g} \mathrm{~L}^{-1} ; 250 \mathrm{~W} \text { high-pressure } \\
\text { sodium lamp }(\lambda>400 \mathrm{~nm}) ; \mathrm{O}_{2}\end{array}$ & $26000 \mu \mathrm{mol}(12 \mathrm{~h})$ & 2167 & [111] \\
\hline C doping & $\begin{array}{l}\text { Thermal polymerization of melamine and sonication } \\
\text { with glucose }\end{array}$ & 5/95 (v/v) propan-2-ol/water; $1.0 \mathrm{~g} \mathrm{~L}^{-1} ; 300 \mathrm{~W}$ Xe lamp; $\mathrm{O}_{2}$ & $38.1 \mu \mathrm{mol}(4 \mathrm{~h})$ & 318 & [112] \\
\hline
\end{tabular}


Table 1. Cont

\begin{tabular}{|c|c|c|c|c|c|}
\hline \multirow[b]{2}{*}{ Modification on CN } & \multirow[b]{2}{*}{ Preparation Method } & \multirow[b]{2}{*}{ Experimental Conditions } & \multicolumn{2}{|l|}{ Photocatalytic Results } & \multirow[b]{2}{*}{ Ref. } \\
\hline & & & $\mathrm{H}_{2} \mathrm{O}_{2}$ Generated $(\mu \mathrm{mol})$ & $\begin{array}{l}\text { Production Rate ( } \mu \mathrm{mol} \\
\mathrm{g}_{\left.\mathrm{cat}^{-1} \mathrm{~h}^{-1}\right)}\end{array}$ & \\
\hline Carbon nanotubes combination & $\begin{array}{l}\text { Thermal polymerization of dicyandiamide and } \\
\text { ammonium chloride and mixed with carbon } \\
\text { nanotubes }\end{array}$ & $\begin{array}{l}5 / 95(v / v) \text { formic acid/water }(100 \mathrm{~mL}) ; 1.0 \mathrm{~g} \mathrm{~L}^{-1} ; 300 \mathrm{~W} \text { Xe lamp } \\
(\lambda \geq 400 \mathrm{~nm}) ; \mathrm{O}_{2}\end{array}$ & $48.7 \mu \mathrm{mol}(1 \mathrm{~h})$ & 487 & {$[106]$} \\
\hline Carbon nanotubes combination & $\begin{array}{l}\text { Thermal polymerization of dicyandiamide and } \\
\text { ammonium chloride and mixed with carbon } \\
\text { nanotubes }\end{array}$ & $\begin{array}{l}5 / 95(v / v) \text { methanol/water }(100 \mathrm{~mL}) ; 1.0 \mathrm{~g} \mathrm{~L}^{-1} ; 300 \mathrm{~W} \text { Xe lamp }(\lambda \\
\geq 400 \mathrm{~nm}) ; \mathrm{O}_{2}\end{array}$ & $23.1 \mu \mathrm{mol}(1 \mathrm{~h})$ & 231 & {$[106]$} \\
\hline Carbon nanotubes combination & $\begin{array}{l}\text { Thermal polymerization of dicyandiamide and } \\
\text { ammonium chloride and mixed with carbon } \\
\text { nanotubes }\end{array}$ & water $(100 \mathrm{~mL}) ; 1.0 \mathrm{~g} \mathrm{~L}^{-1} ; 300 \mathrm{~W}$ Xe lamp $(\lambda \geq 400 \mathrm{~nm}) ; \mathrm{O}_{2}$ & $1.3 \mu \mathrm{mol}(1 \mathrm{~h})$ & 13 & {$[106]$} \\
\hline AQ-COOH coupling & $\begin{array}{l}\text { Thermal polymerization of melamine and sonication } \\
\text { with anthraquinone (AQ)-2-carboxylic acid }\end{array}$ & $\begin{array}{l}\text { 1/9 (v/v) propan-2-ol/water; } 0.5 \mathrm{~g} \mathrm{~L}^{-1} ; 150 \mathrm{~W} \text { Xe lamp }(\lambda>400 \\
\mathrm{nm}) ; \mathrm{O}_{2}\end{array}$ & no data & 361 & {$[108]$} \\
\hline AQ-COOH coupling & $\begin{array}{l}\text { Thermal polymerization of melamine and sonication } \\
\text { with anthraquinone-2-carboxylic acid }\end{array}$ & $\begin{array}{l}\text { 1/9 (v/v) propan-2-ol/water; } 0.5 \mathrm{~g} \mathrm{~L}^{-1} ; 150 \mathrm{~W} \text { Xe lamp }(\lambda>400 \\
\mathrm{nm}) \text {; air }\end{array}$ & no data & 270 & {$[108]$} \\
\hline AQ-NH ${ }_{2}$ coupling & $\begin{array}{l}\text { Thermal polymerization of melamine and sonication } \\
\text { with 2-aminoanthraquinone }\end{array}$ & $\begin{array}{l}\text { 1/9 (v/v) propan-2-ol/water; } 0.5 \mathrm{~g} \mathrm{~L}^{-1} ; 150 \mathrm{~W} \text { Xe lamp }(\lambda>400 \\
\mathrm{nm}) ; \mathrm{O}_{2}\end{array}$ & no data & 233 & {$[108]$} \\
\hline $\mathrm{AQ}-\mathrm{SO}_{3}{ }^{-}$coupling & $\begin{array}{l}\text { Thermal polymerization of melamine and sonication } \\
\text { with sodium anthraquinone-2-sulfonate }\end{array}$ & $\begin{array}{l}\text { 1/9 (v/v) propan-2-ol/water; } 0.5 \mathrm{~g} \mathrm{~L}^{-1} ; 150 \mathrm{~W} \text { Xe lamp }(\lambda>400 \\
\mathrm{nm}) ; \mathrm{O}_{2}\end{array}$ & no data & 131 & {$[108]$} \\
\hline AQ-OH coupling & $\begin{array}{l}\text { Thermal polymerization of melamine and sonication } \\
\text { with 2-hydroxymethylanthraquinone }\end{array}$ & $\begin{array}{l}\text { 1/9 (v/v) propan-2-ol/water; } 0.5 \mathrm{~g} \mathrm{~L}^{-1} ; 150 \mathrm{~W} \text { Xe lamp }(\lambda>400 \\
\mathrm{nm}) ; \mathrm{O}_{2}\end{array}$ & no data & 86.9 & {$[108]$} \\
\hline AQ-COOH coupling & $\begin{array}{l}\text { Thermal polymerization of melamine and sonication } \\
\text { with anthraquinone-2-carboxylic acid }\end{array}$ & water; $0.5 \mathrm{~g} \mathrm{~L}^{-1} ; 150 \mathrm{~W}$ Xe lamp $(\lambda>400 \mathrm{~nm}) ; \mathrm{O}_{2}$ & no data & 24 & {$[108]$} \\
\hline Benzene substitution & Thermal polymerization of urea with trimesic acid & $\begin{array}{l}1 / 9(v / v) \text { ethanol/water }(30 \mathrm{~mL}) ; 0.5 \mathrm{~g} \mathrm{~L}^{-1} ; 300 \mathrm{~W} \text { Xe lamp }(\lambda> \\
420 \mathrm{~nm}) ; \mathrm{O}_{2}\end{array}$ & $275 \mu \mathrm{mol}(3 \mathrm{~h})$ & 300 & {$[114]$} \\
\hline $\mathrm{N}$ doping & $\begin{array}{l}\text { Thermal polymerization of melamine, sonication with } \\
\text { tetracycline hydrochloride and further thermal } \\
\text { exfoliation }\end{array}$ & $\begin{array}{l}3 / 7(v / v) \text { propan-2-ol/water }(100 \mathrm{~mL}) ; 0.5 \mathrm{~g} \mathrm{~L}^{-1} \text {; solar simulator } \\
(\lambda>420 \mathrm{~nm}) ; \mathrm{O}_{2}\end{array}$ & $14 \mu \mathrm{mol}(1 \mathrm{~h})$ & 279 & [115] \\
\hline O doping & $\begin{array}{l}\text { Thermal polymerization of dicyandiamide with nitric } \\
\text { acid and hydrothermal post-treatment }\end{array}$ & $\begin{array}{l}\text { water }(50 \mathrm{~mL}) ; 1.0 \mathrm{~g} \mathrm{~L}^{-1} ; 250 \mathrm{~W} \text { high-pressure sodium lamp ( } \lambda \\
>400 \mathrm{~nm}) ; \mathrm{O}_{2}\end{array}$ & $760 \mu \mathrm{mol}(6 \mathrm{~h})$ & 633 & [116] \\
\hline Phosphate doping & $\begin{array}{l}\text { Thermal polymerization of melamine and } \\
\text { hydrothermal treatment with } \mathrm{H}_{3} \mathrm{PO}_{4}\end{array}$ & $\begin{array}{l}\text { 2.6 mM EDTA aqueous solution }(200 \mathrm{~mL}) ; 1.0 \mathrm{~g} \mathrm{~L}^{-1} ; 250 \mathrm{~W} \\
\text { high-pressure sodium lamp }(\lambda>400 \mathrm{~nm}) ; \mathrm{O}_{2}\end{array}$ & $1080 \mu \mathrm{mol}(6 \mathrm{~h})$ & 900 & [117] \\
\hline $\mathrm{CN}-\mathrm{C}_{60}$ & Thermal polymerization of melamine and $\mathrm{C}_{60}$ & $\begin{array}{l}\text { 1/9 (v/v) propan-2-ol/water; } 0.5 \mathrm{~g} \mathrm{~L}^{-1} ; 150 \mathrm{~W} \text { Xe lamp }(\lambda>400 \\
\mathrm{nm}) ; \mathrm{O}_{2}\end{array}$ & no data & 63.2 & [108] \\
\hline CN-GO & $\begin{array}{l}\text { Thermal polymerization of melamine and sonication } \\
\text { with GO }\end{array}$ & $\begin{array}{l}\text { 1/9 (v/v) propan-2-ol/water; } 0.5 \mathrm{~g} \mathrm{~L}^{-1} ; 150 \mathrm{~W} \text { Xe lamp }(\lambda>400 \\
\mathrm{nm}) ; \mathrm{O}_{2}\end{array}$ & no data & 62.3 & [108] \\
\hline CN-rGO & $\begin{array}{l}\text { Thermal polymerization of melamine and sonication } \\
\text { with hydrazine-reduced GO }\end{array}$ & $\begin{array}{l}\text { 1/9 (v/v) propan-2-ol/water; } 0.5 \mathrm{~g} \mathrm{~L}^{-1} ; 150 \mathrm{~W} \text { Xe lamp }(\lambda>400 \\
\mathrm{nm}) ; \mathrm{O}_{2}\end{array}$ & no data & 74.3 & [108] \\
\hline
\end{tabular}


Table 1. Cont

\begin{tabular}{|c|c|c|c|c|c|}
\hline \multirow[b]{2}{*}{ Modification on CN } & \multirow[b]{2}{*}{ Preparation Method } & \multirow[b]{2}{*}{ Experimental Conditions } & \multicolumn{2}{|l|}{ Photocatalytic Results } & \multirow[b]{2}{*}{ Ref. } \\
\hline & & & $\mathrm{H}_{2} \mathrm{O}_{2}$ Generated $(\mu \mathrm{mol})$ & $\begin{array}{l}\text { Production Rate }(\mu \mathrm{mol} \\
\left.\mathrm{g}_{\mathrm{cat}^{-1}} \mathrm{~h}^{-1}\right)\end{array}$ & \\
\hline CN-PDI & $\begin{array}{l}\text { Thermal polymerization of melamine and } \\
\text { pyromellitic dianhydride (PMDA) }\end{array}$ & water $(30 \mathrm{~mL}) ; 1.7 \mathrm{~g} \mathrm{~L}^{-1} ; 2000 \mathrm{~W}$ Xe lamp $(\lambda>420 \mathrm{~nm}) ; \mathrm{O}_{2}$ & $50.6 \mu \mathrm{mol}(48 \mathrm{~h})$ & 21 & [107] \\
\hline CN-PDI & $\begin{array}{l}\text { Thermal polymerization of melamine and } \\
\text { pyromellitic dianhydride (PMDA) }\end{array}$ & $\begin{array}{l}\text { 9/1 (v/v) propan-2-ol/water }(30 \mathrm{~mL}) ; 1.7 \mathrm{~g} \mathrm{~L}^{-1} ; 2000 \mathrm{~W} \text { Xe lamp } \\
(\lambda>420 \mathrm{~nm}) ; \mathrm{O}_{2}\end{array}$ & $210 \mu \mathrm{mol}(6 \mathrm{~h})$ & 700 & [107] \\
\hline CN-BDI & $\begin{array}{l}\text { Thermal polymerization of melamine and biphenyl } \\
\text { tetracarboxylic dianhydride (BTCDA) }\end{array}$ & $\begin{array}{l}\text { 9/1 (v/v) propan-2-ol/water }(30 \mathrm{~mL}) ; 3.3 \mathrm{~g} \mathrm{~L}^{-1} \text {; solar simulator }(\lambda \\
>400-500 \mathrm{~nm}) ; \mathrm{O}_{2}\end{array}$ & $22.2 \mu \mathrm{mol}(2 \mathrm{~h})$ & 111 & [77] \\
\hline CN-BDI & $\begin{array}{l}\text { Thermal polymerization of melamine and biphenyl } \\
\text { tetracarboxylic dianhydride (BTCDA) }\end{array}$ & water $(30 \mathrm{~mL}) ; 1.7 \mathrm{~g} \mathrm{~L}^{-1}$; solar simulator $(\lambda>420 \mathrm{~nm}) ; \mathrm{O}_{2}$ & $11.6 \mu \mathrm{mol}(24 \mathrm{~h})$ & 10 & [77] \\
\hline CN-MTI & $\begin{array}{l}\text { Thermal polymerization of melem and mellitic acid } \\
\text { trianhydride (MTA) }\end{array}$ & water $(30 \mathrm{~mL}) ; 1.7 \mathrm{~g} \mathrm{~L}^{-1}$; Xe lamp $(\lambda>420 \mathrm{~nm}) ; \mathrm{O}_{2}$ & $27.5 \mu \mathrm{mol}(24 \mathrm{~h})$ & 23 & [78] \\
\hline CN-PDI-rGO & $\begin{array}{l}\text { Hydrothermal treatment of melem and GO and } \\
\text { thermal polymerization with PMDA }\end{array}$ & water $(30 \mathrm{~mL}) ; 1.7 \mathrm{~g} \mathrm{~L}^{-1} ; 2000 \mathrm{~W}$ Xe lamp $(\lambda>420 \mathrm{~nm}) ; \mathrm{O}_{2}$ & $60 \mu \mathrm{mol}(48 \mathrm{~h})$ & 25 & [119] \\
\hline CN-PDI-rGO & $\begin{array}{l}\text { Hydrothermal treatment of melem and GO and } \\
\text { thermal polymerization with PMDA }\end{array}$ & $\begin{array}{l}\text { 9/1 (v/v) propan-2-ol/water }(30 \mathrm{~mL}) ; 1.7 \mathrm{~g} \mathrm{~L}^{-1} ; 2000 \mathrm{~W} \text { Xe lamp } \\
(\lambda>420 \mathrm{~nm}) ; \mathrm{O}_{2}\end{array}$ & $550 \mu \mathrm{mol}(9 \mathrm{~h})$ & 1222 & [119] \\
\hline CN-PDI-BN & $\begin{array}{l}\text { Sonication of melem and } \mathrm{CN} \text { and thermal } \\
\text { polymerization with PMDA }\end{array}$ & water $(30 \mathrm{~mL}) ; 1.7 \mathrm{~g} \mathrm{~L}^{-1} ; 200 \mathrm{~W}$ Xe lamp $(\lambda>420 \mathrm{~nm}) ; \mathrm{O}_{2}$ & $28 \mu \mathrm{mol}(24 \mathrm{~h})$ & 23 & [122] \\
\hline CN-PDI-BN & $\begin{array}{l}\text { Sonication of melem and } \mathrm{CN} \text { and thermal } \\
\text { polymerization with PMDA }\end{array}$ & $\begin{array}{l}\text { 9/1 (v/v) propan-2-ol/water }(30 \mathrm{~mL}) ; 1.7 \mathrm{~g} \mathrm{~L}^{-1} ; 200 \mathrm{~W} \text { Xe lamp }(\lambda \\
>420 \mathrm{~nm}) ; \mathrm{O}_{2}\end{array}$ & $370 \mu \mathrm{mol}(6 \mathrm{~h})$ & 1233 & [122] \\
\hline CN-PDI-rGO-BN & $\begin{array}{l}\text { Sonication of melem, GO and } \mathrm{CN} \text { and thermal } \\
\text { polymerization with PMDA }\end{array}$ & water $(30 \mathrm{~mL}) ; 1.7 \mathrm{~g} \mathrm{~L}^{-1} ; 200 \mathrm{~W}$ Xe lamp $(\lambda>420 \mathrm{~nm}) ; \mathrm{O}_{2}$ & $37 \mu \mathrm{mol}(24 \mathrm{~h})$ & 31 & [122] \\
\hline CN-PDI-rGO-BN & $\begin{array}{l}\text { Sonication of melem, GO and } \mathrm{CN} \text { and thermal } \\
\text { polymerization with PMDA }\end{array}$ & $\begin{array}{l}\text { 9/1 (v/v) propan-2-ol/water }(30 \mathrm{~mL}) ; 1.7 \mathrm{~g} \mathrm{~L}^{-1} ; 200 \mathrm{~W} \text { Xe lamp }(\lambda \\
>420 \mathrm{~nm}) ; \mathrm{O}_{2}\end{array}$ & $550 \mu \mathrm{mol}(6 \mathrm{~h})$ & 1833 & [122] \\
\hline CN-PI & $\begin{array}{l}\text { Thermal polymerization of melamine and cyanuric } \\
\text { acid and reflux condensation reaction with perylene } \\
\text { tetracarboxylic dianyhdride (PTCDA) and imidazole }\end{array}$ & water $(30 \mathrm{~mL}) ; 1.7 \mathrm{~g} \mathrm{~L}^{-1} ; 300 \mathrm{~W}$ Xe lamp $(\lambda>420 \mathrm{~nm})$; no data & $120 \mu \mathrm{mol}(2 \mathrm{~h})$ & 1200 & [96] \\
\hline CN-BP & $\begin{array}{l}\text { Thermal polymerization of urea followed by } \\
\text { sonication with N-methyl-2-pyrrolidone and BP }\end{array}$ & $\begin{array}{l}1 / 9(v / v) \text { propan-2-ol/water }(30 \mathrm{~mL}) ; 1.7 \mathrm{~g} \mathrm{~L}^{-1} ; 300 \mathrm{~W} \text { Xe lamp }(\lambda \\
>420 \mathrm{~nm}) ; \mathrm{O}_{2}\end{array}$ & $540 \mu \mathrm{mol}(1 \mathrm{~h})$ & 540 & [124] \\
\hline CN-BN & $\begin{array}{l}\text { Hydrothermal treatment and thermal polymerization } \\
\text { of thiourea and melamine and sonication with BN } \\
\text { dots }\end{array}$ & $\begin{array}{l}\text { 1/9 (v/v) propan-2-ol/water }(50 \mathrm{~mL}) ; 1.0 \mathrm{~g} \mathrm{~L}^{-1} ; 300 \mathrm{~W} \text { Xe lamp }(\lambda \\
>420 \mathrm{~nm}) ; \mathrm{O}_{2}\end{array}$ & $72.3 \mu \mathrm{mol}(1 \mathrm{~h})$ & 72.3 & [120] \\
\hline CN-BN & Thermal polymerization of urea and BN nanosheets & $\begin{array}{l}1 / 9(v / v) \text { methanol/water }(40 \mathrm{~mL}) ; 0.5 \mathrm{~g} \mathrm{~L}^{-1} ; 300 \mathrm{~W} \text { Xe lamp }(\lambda> \\
305 \mathrm{~nm}) ; \mathrm{O}_{2}\end{array}$ & $112 \mu \mathrm{mol}(4 \mathrm{~h})$ & 1400 & [121] \\
\hline
\end{tabular}




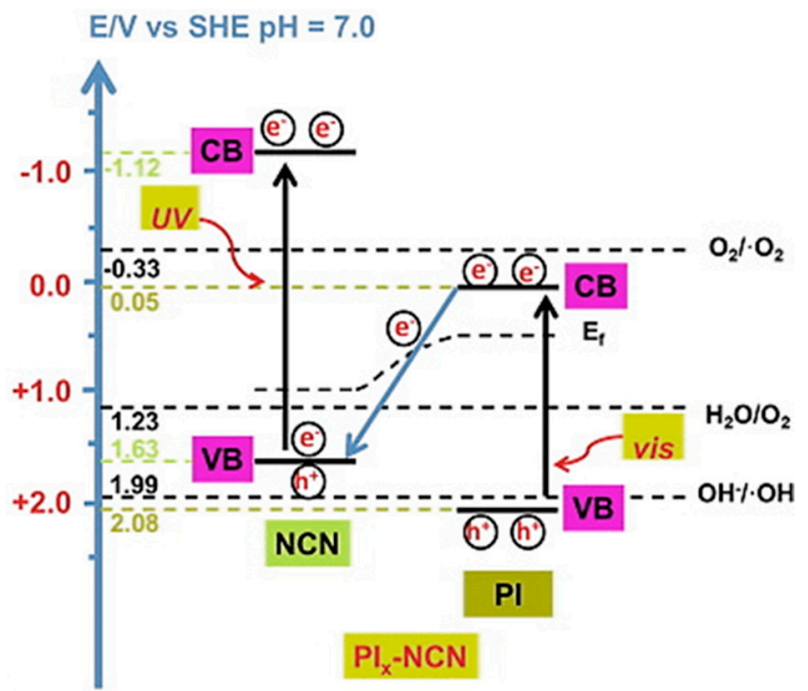

Figure 9. Energy diagram for the Z-scheme structure of the CN-perylene imide (PI) photocatalyst.

Adapted with permission from reference [96]. Copyright 2017 Elsevier B.V.

The combination of $\mathrm{CN}$ and black phosphorus (BP) was reported by Zheng et al. [124]. This composite allowed for a higher $\mathrm{H}_{2} \mathrm{O}_{2}$ productivity than the lone $\mathrm{CN}$, owing to $\mathrm{BP}$ being highly reactive to oxygen.

To compare the different structures and experimental conditions by an unbiased parameter, the apparent quantum yield (AQY) and the solar-to-chemical conversion (SCC) of $\mathrm{H}_{2} \mathrm{O}_{2}$ production are typically applied. These coefficients were calculated by the respective authors and were collected in Table 2. The AQY gives the information about the formation of $\mathrm{H}_{2} \mathrm{O}_{2}$ relative to the number of incident photons and relates the stoichiometric amount of $\mathrm{H}_{2} \mathrm{O}_{2}$ formed with a specific light intensity and emission wavelength [125]. The SCC is related to the performance of a catalyst to yield $\mathrm{H}_{2} \mathrm{O}_{2}$, relating the free energy of $\mathrm{H}_{2} \mathrm{O}_{2}$ formation and the total incident energy [125]. Therefore, higher AQY and SCC values can demonstrate the photoactivity efficiency and proneness to selectively generate $\mathrm{H}_{2} \mathrm{O}_{2}$. For instance, Kofuji et al. [122] reported the hybrid CN-PDI-BN-rGO, which yielded the highest reported values of AQY and SCC compared to other works, as well as the highest rates for $\mathrm{H}_{2} \mathrm{O}_{2}$ production.

Table 2. Solar-to-chemical conversion (SCC) and apparent quantum yield (AQY) efficiencies for some studies. $\mathrm{Nv}=$ nitrogen vacancies.

\begin{tabular}{lccc}
\hline \multicolumn{1}{c}{ Material } & AQY/\% & SCC/\% & Ref. \\
\hline CN-PDI & 2.6 & 0.10 & {$[77]$} \\
CN-PI & 3.2 & no data & {$[96]$} \\
CN-Nv & 4.3 & 0.26 & {$[110]$} \\
CN-BDI & 4.6 & 0.13 & {$[77]$} \\
CN-PDI-BN & 4.8 & 0.19 & {$[122]$} \\
CN-MTI & 6.0 & 0.18 & {$[78]$} \\
CN-PDI-rGO & 6.1 & 0.20 & {$[119]$} \\
CN-PDI-BN-rGO & 7.3 & 0.27 & {$[122]$} \\
\hline
\end{tabular}

\section{Photocatalytic Application with In Situ $\mathrm{H}_{2} \mathrm{O}_{2}$ Generation}

$\mathrm{H}_{2} \mathrm{O}_{2}$ is used in numerous applications and, due to its oxidizing power, is commonly added in many systems, namely in the abatement of organic contaminants and in fine chemistry, to improve conversion and accelerate the reaction. For instance, the application of sonochemistry has been reported for the simultaneous in situ generation of $\mathrm{H}_{2} \mathrm{O}_{2}$ and degradation of organics [39,40]. The coupling of ultrasounds and photocatalysts (sonophotocatalysis) has been employed for the degradation of 
phenol and 4-chlorophenol with titania-based materials, where the presence of in situ evolved $\mathrm{H}_{2} \mathrm{O}_{2}$ markedly improved the degradation process [126]. Particularly, in photocatalysis, the presence of $\mathrm{H}_{2} \mathrm{O}_{2}$ is reported to increase the mineralization or removal rates of several organics [12-19] and enhance the selectivity of photochemical synthesis [6]. Therefore, the in situ generation of $\mathrm{H}_{2} \mathrm{O}_{2}$ in applications in which it is used as reactant is not only an advantage in terms of process design but also in terms of cost reduction, as described in the next sections.

\subsection{Pollutant Degradation}

The photodegradation of organic molecules and removal of biological contaminants using metal-free $\mathrm{CN}$ materials has been extensively investigated. Some works report the addition of $\mathrm{H}_{2} \mathrm{O}_{2}$, resulting in the enhancement of the degradation process [22,127-131]. In most cases, the CN photocatalyst acts as a Fenton-mimic since it turns $\mathrm{H}_{2} \mathrm{O}_{2}$ into $\mathrm{HO} \mathrm{O}^{\bullet}$ which attack the pollutants, leading to increased mineralization $[20,132,133]$. This interesting duality of $\mathrm{CN}$ is worth of being explored, and several authors have already verified the in situ evolution of $\mathrm{H}_{2} \mathrm{O}_{2}$ to enhance the oxidative abatement of contaminants. As previously discussed, metal-free $\mathrm{CN}$, under visible-light, leads to the formation of $\mathrm{H}_{2} \mathrm{O}_{2}$, and is used for the removal of several organic compounds by photocatalysis. Many studies report the formation of $\mathrm{H}_{2} \mathrm{O}_{2}$ simultaneously to the degradation of the contaminant molecules $[20,23,120,134-141]$. The degradation is accompanied by the formation of reactive oxygen species (ROS), $\mathrm{H}_{2} \mathrm{O}_{2}$ being detected during the photocatalytic experiments. Two studies recently followed the time-dependent $\mathrm{H}_{2} \mathrm{O}_{2}$ concentration along the photocatalytic degradation reaction of phenol [95,142]. Zhang et al. detected $\mathrm{H}_{2} \mathrm{O}_{2}$ using $\mathrm{CN}$ nanosheets under visible light irradiation with the production being markedly dependent in the structure of $\mathrm{CN}$, yielding larger amounts for more exfoliated materials which promote selective two-electron $\mathrm{O}_{2}$ reduction [95]. Additionally, the formation of highly reactive oxygen species promoted phenol degradation, such as $\mathrm{HO}^{\bullet}$ originated from $\mathrm{H}_{2} \mathrm{O}_{2}$ decomposition. The presence of $\mathrm{O}_{2}$ in an aqueous solution can lead to the formation of $\mathrm{H}_{2} \mathrm{O}_{2}$ and other reactive oxygen species which aid the oxidation of organic molecules. $\mathrm{H}_{2} \mathrm{O}_{2}$ is a fast reacting molecule; however, its stabilization and production is very dependent of the medium [1]. For instance, the $\mathrm{pH}$ dependency of $\mathrm{H}_{2} \mathrm{O}_{2}$ is known and, in more acidic media, $\mathrm{H}_{2} \mathrm{O}_{2}$ is more stable than in an alkaline environment [143]. However, $\mathrm{CN}$ has been proven to act efficiently in all $\mathrm{pH}$ range since this material presents amphoteric properties [144,145]. Relative to $\mathrm{H}_{2} \mathrm{O}_{2}$ formation, it is observed that many other factors have to be taken into consideration, namely the content in dissolved oxygen, pollutant initial concentration, catalyst load and light source. The work developed by Svoboda et al. [142] somewhat showed the impact of these parameters on $\mathrm{H}_{2} \mathrm{O}_{2}$ production since quenching experiments lead to changes on the degradation of phenol (sacrificial agent for $\mathrm{H}_{2} \mathrm{O}_{2}$ formation). However, the use of scavenging species, to study $\mathrm{H}_{2} \mathrm{O}_{2}$ formation and decomposition, may suffer interference owing to their degradation by different reactive oxy-species. This can hinder or facilitate the generation of $\mathrm{H}_{2} \mathrm{O}_{2}$ leading to ambiguous results. Svoboda et al. [142] investigated the degradation of phenol using $\mathrm{CN}$ nanosheets obtained from the thermal post-treatment of melamine-derived bulk CN. This allowed for an increase of the surface area of the material, leading to much higher photoactivity. In this work, an impressive $\mathrm{H}_{2} \mathrm{O}_{2}$ production rate of $3300 \mu \mathrm{mol} \mathrm{g}_{\mathrm{cat}}{ }^{-1} \mathrm{~h}^{-1}$ was reported, using visible-LEDs with a maximum emission wavelength of $\lambda=416 \mathrm{~nm}$, continuous air purging and a phenol initial concentration of $20 \mathrm{mg} \mathrm{L}^{-1}$.

Furthermore, using differently-substituted phenolic compounds and exfoliated $\mathrm{CN}$ it is possible to obtain high production rates between 633 and $3103 \mu \mathrm{mol} \mathrm{g}_{\mathrm{cat}}{ }^{-1} \mathrm{~h}^{-1}$ [146], using visible-light emitting diodes and continuous air saturation. This study contemplates the relation between $\mathrm{O}_{2}$ concentration and $\mathrm{H}_{2} \mathrm{O}_{2}$ production, establishing that as the dissolved oxygen content increases up to $21 \%$ there is an increase in $\mathrm{H}_{2} \mathrm{O}_{2}$ formation. Moreover, the exfoliated $\mathrm{CN}$ in this work was tested in a propan-2-ol aqueous solution, achieving a $\mathrm{H}_{2} \mathrm{O}_{2}$ production rate of $19,200 \mu \mathrm{mol} \mathrm{g} \mathrm{cat}^{-1} \mathrm{~h}^{-1}$.

To date, the combination of oxidation driven by in situ evolved $\mathrm{H}_{2} \mathrm{O}_{2}$ in $\mathrm{CN}$ photocatalysts with other AOPs for water treatment has been reported for ozonation and persulfate activation [147,148]. 
These two studies investigate the in situ evolution of $\mathrm{H}_{2} \mathrm{O}_{2}$ during the reaction and discuss the synergic effect that promoted the removal of the contaminant molecules. However, it is interesting to point out that $\mathrm{H}_{2} \mathrm{O}_{2}$ is fundamental in the Fenton reaction. In addition, in a homogeneous Fenton system, the treated water matrix remains with dissolved iron which has to be separated. Iron-doped $\mathrm{CN}$ photocatalysts result on the combination of traditional Fenton and $\mathrm{CN}$ photocatalysis which enhances oxidation by promoting a two-channel pathway of $\mathrm{H}_{2} \mathrm{O}_{2}$ reduction to generate $\mathrm{HO}^{\bullet}$. In this way, many authors have synthesized iron-doped $\mathrm{CN}$ to try combat the disadvantage of dissolved iron in the mineralized waters [149-152].

$\mathrm{CN}$ has been applied as metal-free photocatalyst for the degradation of several organic pollutants, but the generation of $\mathrm{H}_{2} \mathrm{O}_{2}$ was not monitored in the publications [153,154]; thus, they are not considered in this review.

\subsection{Fine Chemistry}

In the case of selective organic synthesis, there are reports of $\mathrm{H}_{2} \mathrm{O}_{2}$ addition while employing metal-free $\mathrm{CN}$ photocatalysts $[155,156]$. The presence of $\mathrm{H}_{2} \mathrm{O}_{2}$ improves the oxidation of selected molecules, such as the conversion of toluene to benzaldehyde [155] or of cyclic olefins to the respective epoxides [156]. However, there have been reports where $\mathrm{H}_{2} \mathrm{O}_{2}$ formation was observed in the presence of both visible light and a CN catalyst. Lopes et al. [157] achieved very high production rates of ca. $5000 \mu \mathrm{mol} \mathrm{g} \mathrm{cat}^{-1} \mathrm{~h}^{-1}$ using nanosheets of $\mathrm{CN}$ in an anisyl alcohol solution. In that work, $\mathrm{H}_{2} \mathrm{O}_{2}$ was formed as a by-product of the oxidation of aromatic alcohols into the corresponding aldehydes. The simultaneous formation of $\mathrm{H}_{2} \mathrm{O}_{2}$ is a further advantage to the selective organic synthesis owing to the oxidizing power of $\mathrm{H}_{2} \mathrm{O}_{2}$, such as Zhang et al. [158] describes with an oxygen-enriched $\mathrm{CN}$ material employed for the transformation of amines into imines.

\section{Conclusions and Future Prospects}

This review article summarizes the state-of-the-art on modified metal-free carbon nitride photocatalysts for the selective evolution of $\mathrm{H}_{2} \mathrm{O}_{2}$, a high-value and multi-faceted chemical. Conventional processes for $\mathrm{H}_{2} \mathrm{O}_{2}$ synthesis are generally characterized by high energy consumption and waste generation. The latest studies, employing sustainable metal-free carbon nitride materials and clean aqueous matrices as solvents, show an emergent photocatalytic technology for $\mathrm{H}_{2} \mathrm{O}_{2}$ generation, including the smart tailoring of these materials for optimal conversion. Moreover, the ambivalence of the photocatalytic process, with simultaneous production and direct application of $\mathrm{H}_{2} \mathrm{O}_{2}$, has already been explored for pollutant degradation and fine chemical synthesis. The referred studies provide a favourable starting point to achieve sustainability in the industry of $\mathrm{H}_{2} \mathrm{O}_{2}$ production, albeit more research has to be performed to develop the necessary scale up operation, productivity enhancement, and overall process optimization.

Author Contributions: Conceptualization, all authors; methodology, A.T.-P. and M.J.S.; investigation, A.T.-P.; resources, J.L.F.; C.G.S. and A.M.T.S.; writing—original draft preparation, A.T.-P. and M.J.S.; writing-review and editing, all authors; supervision, C.G.S.; J.L.F. and A.M.T.S.

Funding: This work was financially supported by project NORTE-01-0145-FEDER-031049 (InSpeCt, PTDC/EAM-AMB/31049/2017) funded by the European Regional Development Fund (ERDF) through NORTE 2020 - Programa Operacional Regional do NORTE and by national funds (PIDDAC) through FCT-Fundação para a Ciência e a Tecnologia, and by projects POCI-01-0145-FEDER-030674, POCI-01-0145-FEDER-031398 and POCI-01-0145-FEDER-029600, funded by ERDF through COMPETE2020 - Programa Operacional Competitividade e Internacionalização (POCI) - and by national funds through FCT. We would also like to thank the scientific collaboration under project “AIProcMat@N2020 - Advanced Industrial Processes and Materials for a Sustainable Northern Region of Portugal 2020", with the reference NORTE-01-0145-FEDER-000006, supported by NORTE 2020 under the Portugal 2020 Partnership Agreement through ERDF, and project Associate Laboratory LSRE-LCM - UID/EQU/50020/2019 funded by national funds through FCT/MCTES (PIDDAC). C.G.S. acknowledges the FCT Investigator Programme (IF/00514/2014) with financing from the European Social Fund (ESF) and the Human Potential Operational Programme.

Conflicts of Interest: The authors declare no conflict of interest. 


\section{References}

1. Hess, W.T. Hydrogen Peroxide. In Kirk-Othmer Encyclopedia of Chemical Technology, 5th ed.; John Wiley \& Sons, Inc.: Hoboken, NJ, USA, 2007; Volume 14, pp. 35-79.

2. Samanta, C. Direct synthesis of hydrogen peroxide from hydrogen and oxygen: An overview of recent developments in the process. Appl. Catal. A Gen. 2008, 350, 133-149. [CrossRef]

3. Campos-Martin, J.M.; Blanco-Brieva, G.; Fierro, J.L.G. Hydrogen Peroxide Synthesis: An Outlook beyond the Anthraquinone Process. Angew. Chem. Int. Ed. 2006, 45, 6962-6984. [CrossRef]

4. Asghar, A.; Raman, A.A.A.; Wan Daud, W.M.A. Advanced oxidation processes for in-situ production of hydrogen peroxide/hydroxyl radical for textile wastewater treatment: A review. J. Clean. Prod. 2015, 87, 826-838. [CrossRef]

5. Karmakar, S.R. Chapter 6-Bleaching of textiles. In Chemical Techonology in the Pre-Treatment Processes of Textiles; Elsevier: Amsterdam, The Netherlands, 1999; Volume 12, pp. 160-216.

6. Sato, K.; Aoki, M.; Noyori, R. A “Green" Route to Adipic Acid: Direct Oxidation of Cyclohexenes with 30 Percent Hydrogen Peroxide. Science 1998, 281, 1646-1647. [CrossRef]

7. Yamazaki, S.-I.; Siroma, Z.; Senoh, H.; Ioroi, T.; Fujiwara, N.; Yasuda, K. A fuel cell with selective electrocatalysts using hydrogen peroxide as both an electron acceptor and a fuel. J. Power Sour. 2008, 178, 20-25. [CrossRef]

8. Shaegh, S.A.M.; Nguyen, N.-T.; Ehteshami, S.M.M.; Chan, S.H. A membraneless hydrogen peroxide fuel cell using Prussian Blue as cathode material. Energy Environ. Sci. 2012, 5, 8225-8228. [CrossRef]

9. Yamada, Y.; Yoneda, M.; Fukuzumi, S. A Robust One-Compartment Fuel Cell with a Polynuclear Cyanide Complex as a Cathode for Utilizing $\mathrm{H}_{2} \mathrm{O}_{2}$ as a Sustainable Fuel at Ambient Conditions. Chem. Eur. J. 2013, 19, 11733-11741. [CrossRef] [PubMed]

10. Yang, F.; Cheng, K.; Wu, T.; Zhang, Y.; Yin, J.; Wang, G.; Cao, D. Preparation of Au nanodendrites supported on carbon fiber cloth and its catalytic performance to $\mathrm{H}_{2} \mathrm{O}_{2}$ electroreduction and electrooxidation. RSC Adv. 2013, 3, 5483-5490. [CrossRef]

11. Fukuzumi, S. Bioinspired Energy Conversion Systems for Hydrogen Production and Storage. Eur. J. Inorg. Chem. 2008, 2008, 1351-1362. [CrossRef]

12. Perathoner, S.; Centi, G. Wet hydrogen peroxide catalytic oxidation (WHPCO) of organic waste in agro-food and industrial streams. Top. Catal. 2005, 33, 207-224. [CrossRef]

13. Rokhina, E.V.; Virkutyte, J. Environmental Application of Catalytic Processes: Heterogeneous Liquid Phase Oxidation of Phenol With Hydrogen Peroxide. Crit. Rev. Environ. Sci. Technol. 2010, 41, 125-167. [CrossRef]

14. Debellefontaine, H.; Chakchouk, M.; Foussard, J.N.; Tissot, D.; Striolo, P. Treatment of organic aqueous wastes: Wet air oxidation and wet peroxide oxidation ${ }^{\circledR}$. Environ. Pollut. 1996, 92, 155-164. [CrossRef]

15. Domingues, F.S.; Freitas, T.K.F.D.S.; de Almeida, C.A.; de Souza, R.P.; Ambrosio, E.; Palácio, S.M.; Garcia, J.C. Hydrogen peroxide-assisted photocatalytic degradation of textile wastewater using titanium dioxide and zinc oxide. Environ. Technol. 2017, 40, 1223-1232. [CrossRef] [PubMed]

16. Gomes, H.T.; Miranda, S.M.; Sampaio, M.J.; Silva, A.M.T.; Faria, J.L. Activated carbons treated with sulphuric acid: Catalysts for catalytic wet peroxide oxidation. Catal. Today 2010, 151, 153-158. [CrossRef]

17. Ribeiro, R.S.; Silva, A.M.T.; Figueiredo, J.L.; Faria, J.L.; Gomes, H.T. Removal of 2-nitrophenol by catalytic wet peroxide oxidation using carbon materials with different morphological and chemical properties. Appl. Catal. B Environ. 2013, 140, 356-362. [CrossRef]

18. Ribeiro, R.S.; Silva, A.M.T.; Figueiredo, J.L.; Faria, J.L.; Gomes, H.T. Catalytic wet peroxide oxidation: A route towards the application of hybrid magnetic carbon nanocomposites for the degradation of organic pollutants. A review. Appl. Catal. B Environ. 2016, 187, 428-460. [CrossRef]

19. Ribeiro, R.S.; Silva, A.M.T.; Pastrana-Martínez, L.M.; Figueiredo, J.L.; Faria, J.L.; Gomes, H.T. Graphene-based materials for the catalytic wet peroxide oxidation of highly concentrated 4-nitrophenol solutions. Catal. Today 2015, 249, 204-212. [CrossRef]

20. Cui, Y.; Huang, J.; Fu, X.; Wang, X. Metal-free photocatalytic degradation of 4-chlorophenol in water by mesoporous carbon nitride semiconductors. Catal. Sci. Technol. 2012, 2, 1396-1402. [CrossRef]

21. Yao, Y.; Wu, G.; Lu, F.; Wang, S.; Hu, Y.; Zhang, J.; Huang, W.; Wei, F. Enhanced photo-Fenton-like process over Z-scheme $\mathrm{CoFe}_{2} \mathrm{O}_{4} / \mathrm{g}-\mathrm{C}_{3} \mathrm{~N}_{4}$ Heterostructures under natural indoor light. Environ. Sci. Pollut. Res. 2016, 23, 21833-21845. [CrossRef] 
22. Kumar, A.; Kumar, A.; Sharma, G.; Naushad, M.; Veses, R.C.; Ghfar, A.A.; Stadler, F.J.; Khan, M.R. Solar-driven photodegradation of 17- $\beta$-estradiol and ciprofloxacin from waste water and $\mathrm{CO}_{2}$ conversion using sustainable coal-char/polymeric-g- $\mathrm{C}_{3} \mathrm{~N}_{4} / \mathrm{rGO}$ metal-free nano-hybrids. New. J. Chem. 2017, 41, 10208-10224. [CrossRef]

23. Zhou, C.; Lai, C.; Huang, D.; Zeng, G.; Zhang, C.; Cheng, M.; Hu, L.; Wan, J.; Xiong, W.; Wen, M.; et al. Highly porous carbon nitride by supramolecular preassembly of monomers for photocatalytic removal of sulfamethazine under visible light driven. Appl. Catal. B Environ. 2018, 220, 202-210. [CrossRef]

24. Su, M.; He, C.; Sharma, V.K.; Asi, M.A.; Xia, D.; Li, X.Z.; Deng, H.; Xiong, Y. Mesoporous zinc ferrite: Synthesis, characterization, and photocatalytic activity with $\mathrm{H}_{2} \mathrm{O}_{2}$ /visible light. J. Hazard. Mater. 2012, 211, 95-103. [CrossRef] [PubMed]

25. Jia, Y.; Lee, B.W.; Liu, C. Magnetic $\mathrm{ZnFe}_{2} \mathrm{O}_{4}$ Nanocubes: Synthesis and Photocatalytic Activity with Visible Light $/ \mathrm{H}_{2} \mathrm{O}_{2}$. IEEE Trans. Magn. 2017, 53, 1-5. [CrossRef]

26. Xu, J.; Wang, H.; Gu, H.; Zeng, C.; Yang, Y. Facile synthesis of $\mathrm{Cu}_{2} \mathrm{O}$ nanocubes and their enhanced photocatalytic property assisted by $\mathrm{H}_{2} \mathrm{O}_{2}$. Asian J. Chem. 2013, 25, 1733-1736.

27. Kalam, A.; Al-Sehemi, A.G.; Assiri, M.; Du, G.; Ahmad, T.; Ahmad, I.; Pannipara, M. Modified solvothermal synthesis of cobalt ferrite $\left(\mathrm{CoFe}_{2} \mathrm{O}_{4}\right)$ magnetic nanoparticles photocatalysts for degradation of methylene blue with $\mathrm{H}_{2} \mathrm{O}_{2}$ /visible light. Results Phys. 2018, 8, 1046-1053. [CrossRef]

28. Deng, X.; Wang, C.; Shao, M.; Xu, X.; Huang, J. Low-temperature solution synthesis of $\mathrm{CuO} / \mathrm{Cu}_{2} \mathrm{O}$ nanostructures for enhanced photocatalytic activity with added $\mathrm{H}_{2} \mathrm{O}_{2}$ : Synergistic effect and mechanism insight. RSC Adv. 2017, 7, 4329-4338. [CrossRef]

29. Pesakhov, S.; Benisty, R.; Sikron, N.; Cohen, Z.; Gomelsky, P.; Khozin-Goldberg, I.; Dagan, R.; Porat, N. Effect of hydrogen peroxide production and the Fenton reaction on membrane composition of Streptococcus pneumoniae. BBA Biomembr. 2007, 1768, 590-597. [CrossRef]

30. Pham, A.N.; Xing, G.; Miller, C.J.; Waite, T.D. Fenton-like copper redox chemistry revisited: Hydrogen peroxide and superoxide mediation of copper-catalyzed oxidant production. J. Catal. 2013, 301, 54-64. [CrossRef]

31. Fujihira, M.; Satoh, Y.; Osa, T. Heterogeneous photocatalytic oxidation of aromatic compounds on $\mathrm{TiO}_{2}$. Nature 1981, 293, 206. [CrossRef]

32. Chiou, C.-H.; Wu, C.-Y.; Juang, R.-S. Influence of operating parameters on photocatalytic degradation of phenol in $\mathrm{UV} / \mathrm{TiO}_{2}$ process. Chem. Eng. J. 2008, 139, 322-329. [CrossRef]

33. Nishimi, T.; Kamachi, T.; Kato, K.; Kato, T.; Yoshizawa, K. Mechanistic Study on the Production of Hydrogen Peroxide in the Anthraquinone Process. Eur. J. Org. Chem. 2011, 2011, 4113-4120. [CrossRef]

34. Hans-Joachim, P.G.R. Production of Hydrogen Peroxide. US Patent 2158525, 10 October 1935.

35. Thenard, L.J. Observations sur des nouvelles combinaisons entre l'oxigène et divers acides. Ann. Chim. Phys. 1818, 8, 306-312.

36. Kato, S.; Jung, J.; Suenobu, T.; Fukuzumi, S. Production of hydrogen peroxide as a sustainable solar fuel from water and dioxygen. Energy Environ. Sci. 2013, 6, 3756-3764. [CrossRef]

37. Sandelin, F.; Oinas, P.; Salmi, T.; Paloniemi, J.; Haario, H. Kinetics of the Recovery of Active Anthraquinones. Ind. Eng. Chem. Res. 2006, 45, 986-992. [CrossRef]

38. Lim, M.; Son, Y.; Khim, J. The effects of hydrogen peroxide on the sonochemical degradation of phenol and bisphenol A. Ultrason. Sonochem. 2014, 21, 1976-1981. [CrossRef] [PubMed]

39. Pétrier, C. 31-The use of power ultrasound for water treatment. In Power Ultrasonics; Gallego-Juárez, J.A., Graff, K.F., Eds.; Woodhead Publishing: Oxford, UK, 2015; pp. 939-972.

40. Shende, T.; Andaluri, G.; Suri, R.P.S. Kinetic model for sonolytic degradation of non-volatile surfactants: Perfluoroalkyl substances. Ultrason. Sonochem. 2019, 51, 359-368. [CrossRef] [PubMed]

41. Ziembowicz, S.; Kida, M.; Koszelnik, P. The impact of selected parameters on the formation of hydrogen peroxide by sonochemical process. Sep. Purif. Technol. 2018, 204, 149-153. [CrossRef]

42. Kiss, A.A.; Geertman, R.; Wierschem, M.; Skiborowski, M.; Gielen, B.; Jordens, J.; John, J.J.; Van Gerven, T. Ultrasound-assisted emerging technologies for chemical processes. J. Chem. Technol. Biotechnol. 2018, 93, 1219-1227. [CrossRef]

43. Ashokkumar, M. Advantages, Disadvantages and Challenges of Ultrasonic Technology. In Ultrasonic Synthesis of Functional Materials; Springer International Publishing: Cham, Switzerland, 2016; pp. 41-42.

44. Chinta, S.; Lunsford, J.H. A mechanistic study of $\mathrm{H}_{2} \mathrm{O}_{2}$ and $\mathrm{H}_{2} \mathrm{O}$ formation from $\mathrm{H}_{2}$ and $\mathrm{O}_{2}$ catalyzed by palladium in an aqueous medium. J. Catal. 2004, 225, 249-255. [CrossRef] 
45. Dissanayake, D.P.; Lunsford, J.H. Evidence for the Role of Colloidal Palladium in the Catalytic Formation of $\mathrm{H}_{2} \mathrm{O}_{2}$ from $\mathrm{H}_{2}$ and $\mathrm{O}_{2}$. J. Catal. 2002, 206, 173-176. [CrossRef]

46. Dissanayake, D.P.; Lunsford, J.H. The direct formation of $\mathrm{H}_{2} \mathrm{O}_{2}$ from $\mathrm{H}_{2}$ and $\mathrm{O}_{2}$ over colloidal palladium. J. Catal. 2003, 214, 113-120. [CrossRef]

47. Liu, Q.; Lunsford, J.H. The roles of chloride ions in the direct formation of $\mathrm{H}_{2} \mathrm{O}_{2}$ from $\mathrm{H}_{2}$ and $\mathrm{O}_{2}$ over a $\mathrm{Pd} / \mathrm{SiO}_{2}$ catalyst in a $\mathrm{H}_{2} \mathrm{SO}_{4} /$ ethanol system. J. Catal. 2006, 239, 237-243. [CrossRef]

48. Lunsford, J.H. The direct formation of $\mathrm{H}_{2} \mathrm{O}_{2}$ from $\mathrm{H}_{2}$ and $\mathrm{O}_{2}$ over palladium catalysts. J. Catal. 2003, 216, 455-460. [CrossRef]

49. Choudhary, V.R.; Gaikwad, A.G.; Sansare, S.D. Activation of Supported Pd Metal Catalysts for Selective Oxidation of Hydrogen to Hydrogen Peroxide. Catal. Lett. 2002, 83, 235-239. [CrossRef]

50. Choudhary, V.R.; Samanta, C. Hydrogen peroxide formation in the interaction of oxygen with boron-containing $\mathrm{Pd}$ catalysts prereduced by hydrazine in aqueous acidic medium containing bromide anions. Catal. Lett. 2005, 99, 79-81. [CrossRef]

51. Choudhary, V.R.; Samanta, C.; Gaikwad, A.G. Drastic increase of selectivity for $\mathrm{H}_{2} \mathrm{O}_{2}$ formation in direct oxidation of $\mathrm{H}_{2}$ to $\mathrm{H}_{2} \mathrm{O}_{2}$ over supported $\mathrm{Pd}$ catalysts due to their bromination. Chem. Commun. 2004, 2054-2055. [CrossRef]

52. Choudhary, V.R.; Samanta, C.; Jana, P. A novel route for in-situ $\mathrm{H}_{2} \mathrm{O}_{2}$ generation from selective reduction of $\mathrm{O}_{2}$ by hydrazine using heterogeneous Pd catalyst in an aqueous medium. Chem. Commun. 2005, 5399-5401. [CrossRef]

53. Choudhary, V.R.; Sansare, S.D.; Gaikwad, A.G. Direct Oxidation of $\mathrm{H}_{2}$ to $\mathrm{H}_{2} \mathrm{O}_{2}$ and Decomposition of $\mathrm{H}_{2} \mathrm{O}_{2}$ Over Oxidized and Reduced Pd-Containing Zeolite Catalysts in Acidic Medium. Catal. Lett. 2002, 84, 81-87. [CrossRef]

54. Edwards, J.K.; Hutchings, G.J. Palladium and Gold-Palladium Catalysts for the Direct Synthesis of Hydrogen Peroxide. Angew. Chem. Int. Ed. 2008, 47, 9192-9198. [CrossRef]

55. Edwards, J.K.; Solsona, B.; Landon, P.; Carley, A.F.; Herzing, A.; Watanabe, M.; Kiely, C.J.; Hutchings, G.J. Direct synthesis of hydrogen peroxide from $\mathrm{H}_{2}$ and $\mathrm{O}_{2}$ using $\mathrm{Au}-\mathrm{Pd} / \mathrm{Fe}_{2} \mathrm{O}_{3}$ catalysts. J. Mater. Chem. 2005, 15, 4595-4600. [CrossRef]

56. Edwards, J.K.; Solsona, B.E.; Landon, P.; Carley, A.F.; Herzing, A.; Kiely, C.J.; Hutchings, G.J. Direct synthesis of hydrogen peroxide from $\mathrm{H}_{2}$ and $\mathrm{O}_{2}$ using $\mathrm{TiO}_{2}$-supported Au-Pd catalysts. J. Catal. 2005, 236, 69-79. [CrossRef]

57. Chen, J.; Eberlein, L.; Langford, C.H. Pathways of phenol and benzene photooxidation using $\mathrm{TiO}_{2}$ supported on a zeolite. J. Photochem. Photobiol. A 2002, 148, 183-189. [CrossRef]

58. Ahmed, S.N.; Haider, W. Heterogeneous photocatalysis and its potential applications in water and wastewater treatment: A review. Nanotechnology 2018, 29, 342001. [CrossRef]

59. Radhika, N.P.; Selvin, R.; Kakkar, R.; Umar, A. Recent advances in nano-photocatalysts for organic synthesis. Arab. J. Chem. 2016. [CrossRef]

60. Kaynan, N.; Berke, B.A.; Hazut, O.; Yerushalmi, R. Sustainable photocatalytic production of hydrogen peroxide from water and molecular oxygen. J. Mater. Chem. A 2014, 2, 13822-13826. [CrossRef]

61. Carraway, E.R.; Hoffman, A.J.; Hoffmann, M.R. Photocatalytic Oxidation of Organic Acids on Quantum-Sized Semiconductor Colloids. Environ. Sci. Technol. 1994, 28, 786-793. [CrossRef]

62. Kormann, C.; Bahnemann, D.W.; Hoffmann, M.R. Photocatalytic production of hydrogen peroxides and organic peroxides in aqueous suspensions of titanium dioxide, zinc oxide, and desert sand. Environ. Sci. Technol. 1988, 22, 798-806. [CrossRef]

63. Teranishi, M.; Naya, S.I.; Tada, H. In situ liquid phase synthesis of hydrogen peroxide from molecular oxygen using gold nanoparticle-loaded titanium(IV) dioxide photocatalyst. J. Am. Chem. Soc. 2010, 132, 7850-7851. [CrossRef]

64. Zhuang, H.; Yang, L.; Xu, J.; Li, F.; Zhang, Z.; Lin, H.; Long, J.; Wang, X. Robust Photocatalytic $\mathrm{H}_{2} \mathrm{O}_{2}$ Production by Octahedral $\mathrm{Cd}_{3}\left(\mathrm{C}_{3} \mathrm{~N}_{3} \mathrm{~S}_{3}\right)_{2}$ Coordination Polymer under Visible Light. Sci. Rep. 2015, 5, 16947. [CrossRef]

65. Shao, D.; Zhang, L.; Sun, S.; Wang, W. Oxygen Reduction Reaction for Generating $\mathrm{H}_{2} \mathrm{O}_{2}$ through a Piezo-Catalytic Process over Bismuth Oxychloride. ChemSusChem 2018, 11, 527-531. [CrossRef]

66. Su, Y.; Zhang, L.; Wang, W.; Shao, D. Internal Electric Field Assisted Photocatalytic Generation of Hydrogen Peroxide over BiOCl with HCOOH. ACS Sustain. Chem. Eng. 2018, 6, 8704-8710. [CrossRef] 
67. Isaka, Y.; Kato, S.; Hong, D.; Suenobu, T.; Yamada, Y.; Fukuzumi, S. Bottom-up and top-down methods to improve catalytic reactivity for photocatalytic production of hydrogen peroxide using a Ru-complex and water oxidation catalysts. J. Mater. Chem. A 2015, 3, 12404-12412. [CrossRef]

68. Isaka, Y.; Oyama, K.; Yamada, Y.; Suenobu, T.; Fukuzumi, S. Photocatalytic production of hydrogen peroxide from water and dioxygen using cyano-bridged polynuclear transition metal complexes as water oxidation catalysts. Catal. Sci. Technol. 2016, 6, 681-684. [CrossRef]

69. Isaka, Y.; Yamada, Y.; Suenobu, T.; Nakagawa, T.; Fukuzumi, S. Production of hydrogen peroxide by combination of semiconductor-photocatalysed oxidation of water and photocatalytic two-electron reduction of dioxygen. RSC Adv. 2016, 6, 42041-42044. [CrossRef]

70. Mase, K.; Yoneda, M.; Yamada, Y.; Fukuzumi, S. Efficient Photocatalytic Production of Hydrogen Peroxide from Water and Dioxygen with Bismuth Vanadate and a Cobalt(II) Chlorin Complex. ACS Energy Lett. 2016, 1, 913-919. [CrossRef]

71. Thakur, S.; Kshetri, T.; Kim, N.H.; Lee, J.H. Sunlight-driven sustainable production of hydrogen peroxide using a CdS-graphene hybrid photocatalyst. J. Catal. 2017, 345, 78-86. [CrossRef]

72. Charanpahari, A.; Gupta, N.; Devthade, V.; Ghugal, S.; Bhatt, J. Ecofriendly Nanomaterials for Sustainable Photocatalytic Decontamination of Organics and Bacteria. In Handbook of Ecomaterials; Martínez, L.M.T., Kharissova, O.V., Kharisov, B.I., Eds.; Springer International Publishing: Cham, Switzerland, 2018; pp. 1-29.

73. Chiranjeevi, T.; Pragya, R.; Gupta, S.; Gokak, D.T.; Bhargava, S. Minimization of Waste Spent Catalyst in Refineries. Procedia Environ. Sci. 2016, 35, 610-617. [CrossRef]

74. Monai, M.; Melchionna, M.; Fornasiero, P. Chapter One-From metal to metal-free catalysts: Routes to sustainable chemistry. In Advances in Catalysis; Song, C., Ed.; Academic Press: Cambridge, MA, USA, 2018; Volume 63, pp. 1-73.

75. Gautam, R.K.; Chattopadhyaya, M.C. Chapter 9-Magnetic Nanophotocatalysts for Wastewater Remediation. In Nanomaterials for Wastewater Remediation; Gautam, R.K., Chattopadhyaya, M.C., Eds.; Butterworth-Heinemann: Boston, MA, USA, 2016; pp. 189-238.

76. Shiraishi, Y.; Kanazawa, S.; Sugano, Y.; Tsukamoto, D.; Sakamoto, H.; Ichikawa, S.; Hirai, T. Highly selective production of hydrogen peroxide on graphitic carbon nitride $\left(\mathrm{g}-\mathrm{C}_{3} \mathrm{~N}_{4}\right)$ photocatalyst activated by visible light. ACS Catal. 2014, 4, 774-780. [CrossRef]

77. Kofuji, Y.; Ohkita, S.; Shiraishi, Y.; Sakamoto, H.; Tanaka, S.; Ichikawa, S.; Hirai, T. Graphitic Carbon Nitride Doped with Biphenyl Diimide: Efficient Photocatalyst for Hydrogen Peroxide Production from Water and Molecular Oxygen by Sunlight. ACS Catal. 2016, 6, 7021-7029. [CrossRef]

78. Kofuji, Y.; Ohkita, S.; Shiraishi, Y.; Sakamoto, H.; Ichikawa, S.; Tanaka, S.; Hirai, T. Mellitic Triimide-Doped Carbon Nitride as Sunlight-Driven Photocatalysts for Hydrogen Peroxide Production. ACS Sustain. Chem. Eng. 2017, 5, 6478-6485. [CrossRef]

79. Ong, W.-J.; Tan, L.-L.; Ng, Y.H.; Yong, S.-T.; Chai, S.-P. Graphitic Carbon Nitride (g-C $\left.\mathrm{C}_{3} \mathrm{~N}_{4}\right)$-Based Photocatalysts for Artificial Photosynthesis and Environmental Remediation: Are We a Step Closer To Achieving Sustainability? Chem. Rev. 2016, 116, 7159-7329. [CrossRef] [PubMed]

80. Patnaik, S.; Martha, S.; Acharya, S.; Parida, K.M. An overview of the modification of g- $\mathrm{C}_{3} \mathrm{~N}_{4}$ with high carbon containing materials for photocatalytic applications. Inorg. Chem. Front. 2016, 3, 336-347. [CrossRef]

81. Zhao, Z.; Sun, Y.; Dong, F. Graphitic carbon nitride based nanocomposites: A review. Nanoscale 2015, 7, 15-37. [CrossRef] [PubMed]

82. Zhang, G.; Lan, Z.A.; Wang, X. Surface engineering of graphitic carbon nitride polymers with cocatalysts for photocatalytic overall water splitting. Chem. Sci. 2017, 8, 5261-5274. [CrossRef]

83. Mamba, G.; Mishra, A.K. Graphitic carbon nitride $\left(\mathrm{g}-\mathrm{C}_{3} \mathrm{~N}_{4}\right)$ nanocomposites: A new and exciting generation of visible light driven photocatalysts for environmental pollution remediation. Appl. Catal. B Environ. 2016, 198, 347-377. [CrossRef]

84. Lima, M.J.; Silva, A.M.T.; Silva, C.G.; Faria, J.L. Graphitic carbon nitride modified by thermal, chemical and mechanical processes as metal-free photocatalyst for the selective synthesis of benzaldehyde from benzyl alcohol. J. Catal. 2017, 353, 44-53. [CrossRef]

85. Wang, Y.; Wang, X.; Antonietti, M. Polymeric Graphitic Carbon Nitride as a Heterogeneous Organocatalyst: From Photochemistry to Multipurpose Catalysis to Sustainable Chemistry. Angew. Chem. Int. Ed. 2012, 51, 68-89. [CrossRef] 
86. Domcke, W.; Ehrmaier, J.; Sobolewski, A.L. Solar Energy Harvesting with Carbon Nitrides and N-Heterocyclic Frameworks: Do We Understand the Mechanism? ChemPhotoChem 2019, 3, 10-23. [CrossRef]

87. Corp, K.L.; Schlenker, C.W. Ultrafast Spectroscopy Reveals Electron-Transfer Cascade That Improves Hydrogen Evolution with Carbon Nitride Photocatalysts. J. Am. Chem. Soc. 2017, 139, 7904-7912. [CrossRef]

88. Haider, Z.; Cho, H.-I.; Moon, G.-H.; Kim, H.-I. Minireview: Selective production of hydrogen peroxide as a clean oxidant over structurally tailored carbon nitride photocatalysts. Catal. Today 2018, 335, 55-64. [CrossRef]

89. Goto, H.; Hanada, Y.; Ohno, T.; Matsumura, M. Quantitative analysis of superoxide ion and hydrogen peroxide produced from molecular oxygen on photoirradiated $\mathrm{TiO}_{2}$ particles. J. Catal. 2004, 225, 223-229. [CrossRef]

90. Maurino, V.; Minero, C.; Mariella, G.; Pelizzetti, E. Sustained production of $\mathrm{H}_{2} \mathrm{O}_{2}$ on irradiated TiO - Fluoride systems. Chem. Commun. 2005, 2627-2629. [CrossRef] [PubMed]

91. Hirakawa, T.; Nosaka, Y. Selective Production of Superoxide Ions and Hydrogen Peroxide over Nitrogenand Sulfur-Doped $\mathrm{TiO}_{2}$ Photocatalysts with Visible Light in Aqueous Suspension Systems. J. Phys. Chem. C 2008, 112, 15818-15823. [CrossRef]

92. Tsukamoto, D.; Shiro, A.; Shiraishi, Y.; Sugano, Y.; Ichikawa, S.; Tanaka, S.; Hirai, T. Photocatalytic $\mathrm{H}_{2} \mathrm{O}_{2}$ Production from Ethanol $/ \mathrm{O}_{2}$ System Using $\mathrm{TiO}_{2}$ Loaded with $\mathrm{Au}-\mathrm{Ag}$ Bimetallic Alloy Nanoparticles. ACS Catal. 2012, 2, 599-603. [CrossRef]

93. Cai, R.; Kubota, Y.; Fujishima, A. Effect of copper ions on the formation of hydrogen peroxide from photocatalytic titanium dioxide particles. J. Catal. 2003, 219, 214-218. [CrossRef]

94. Shiraishi, Y.; Kofuji, Y.; Sakamoto, H.; Tanaka, S.; Ichikawa, S.; Hirai, T. Effects of Surface Defects on Photocatalytic $\mathrm{H}_{2} \mathrm{O}_{2}$ Production by Mesoporous Graphitic Carbon Nitride under Visible Light Irradiation. ACS Catal. 2015, 5, 3058-3066. [CrossRef]

95. Zhang, H.; Guo, L.-H.; Zhao, L.; Wan, B.; Yang, Y. Switching Oxygen Reduction Pathway by Exfoliating Graphitic Carbon Nitride for Enhanced Photocatalytic Phenol Degradation. J. Phys. Chem. Lett. 2015, 6, 958-963. [CrossRef]

96. Yang, L.; Dong, G.; Jacobs, D.L.; Wang, Y.; Zang, L.; Wang, C. Two-channel photocatalytic production of $\mathrm{H}_{2} \mathrm{O}_{2}$ over g- $\mathrm{C}_{3} \mathrm{~N}_{4}$ nanosheets modified with perylene imides. J. Catal. 2017, 352, 274-281. [CrossRef]

97. Perry, S.C.; Pangotra, D.; Vieira, L.; Csepei, L.-I.; Sieber, V.; Wang, L.; Ponce de León, C.; Walsh, F.C. Electrochemical synthesis of hydrogen peroxide from water and oxygen. Nat. Rev. Chem. 2019, 3, 442-458. [CrossRef]

98. Cui, Y.; Ding, Z.; Liu, P.; Antonietti, M.; Fu, X.; Wang, X. Metal-free activation of $\mathrm{H}_{2} \mathrm{O}_{2}$ by g- $\mathrm{C}_{3} \mathrm{~N}_{4}$ under visible light irradiation for the degradation of organic pollutants. Phys. Chem. Chem. Phys. 2012, 14, 1455-1462. [CrossRef]

99. Chen, J.; Wagner, P.; Tong, L.; Wallace, G.G.; Officer, D.L.; Swiegers, G.F. A Porphyrin-Doped Polymer Catalyzes Selective, Light-Assisted Water Oxidation in Seawater. Angew. Chem. Int. Ed. 2012, 51, 1907-1910. [CrossRef] [PubMed]

100. Koppenol, W.H. Oxygen Activation by Cytochrome P450: A Thermodynamic Analysis. J. Am. Chem. Soc. 2007, 129, 9686-9690. [CrossRef] [PubMed]

101. David, A.A.; Robert, E.H.; Willem,H.K.; Sergei, V.L.; Merényi, G.; Neta, P.; Ruscic, B.; David, M.S.; Steenken, S.; Wardman, P. Standard electrode potentials involving radicals in aqueous solution: Inorganic radicals (IUPAC Technical Report). Pure Appl. Chem. 2015, 87, 1139.

102. Ghaly, M.Y.; Härtel, G.; Mayer, R.; Haseneder, R. Photochemical oxidation of p-chlorophenol by UV/ $\mathrm{H}_{2} \mathrm{O}_{2}$ and photo-Fenton process. A comparative study. Waste Manag. 2001, 21, 41-47. [CrossRef]

103. Macías-Sánchez, J.; Hinojosa-Reyes, L.; Guzmán-Mar, J.L.; Peralta-Hernández, J.M.; Hernández-Ramírez, A. Performance of the photo-Fenton process in the degradation of a model azo dye mixture. Photochem. Photobiol. Sci. 2011, 10, 332-337. [CrossRef]

104. Pérez-Moya, M.; Graells, M.; Castells, G.; Amigó, J.; Ortega, E.; Buhigas, G.; Pérez, L.M.; Mansilla, H.D. Characterization of the degradation performance of the sulfamethazine antibiotic by photo-Fenton process. Water Res. 2010, 44, 2533-2540. [CrossRef]

105. Li, S.; Dong, G.; Hailili, R.; Yang, L.; Li, Y.; Wang, F.; Zeng, Y.; Wang, C. Effective photocatalytic $\mathrm{H}_{2} \mathrm{O}_{2}$ production under visible light irradiation at $\mathrm{g}-\mathrm{C}_{3} \mathrm{~N}_{4}$ modulated by carbon vacancies. Appl. Catal. B Environ. 2016, 190, 26-35. [CrossRef] 
106. Zhao, S.; Guo, T.; Li, X.; Xu, T.; Yang, B.; Zhao, X. Carbon nanotubes covalent combined with graphitic carbon nitride for photocatalytic hydrogen peroxide production under visible light. Appl. Catal. B Environ. 2018, 224, 725-732. [CrossRef]

107. Shiraishi, Y.; Kanazawa, S.; Kofuji, Y.; Sakamoto, H.; Ichikawa, S.; Tanaka, S.; Hirai, T. Sunlight-driven hydrogen peroxide production from water and molecular oxygen by metal-free photocatalysts. Angew. Chem. Int. Ed. 2014, 53, 13454-13459. [CrossRef]

108. Kim, H.-I.; Choi, Y.; Hu, S.; Choi, W.; Kim, J.-H. Photocatalytic hydrogen peroxide production by anthraquinone-augmented polymeric carbon nitride. Appl. Catal. B Environ. 2018, 229, 121-129. [CrossRef]

109. Shi, L.; Yang, L.; Zhou, W.; Liu, Y.; Yin, L.; Hai, X.; Song, H.; Ye, J. Photoassisted Construction of Holey Defective g- $\mathrm{C}_{3} \mathrm{~N}_{4}$ Photocatalysts for Efficient Visible-Light-Driven $\mathrm{H}_{2} \mathrm{O}_{2}$ Production. Small 2018, 14, 1703142. [CrossRef] [PubMed]

110. Zhu, Z.; Pan, H.; Murugananthan, M.; Gong, J.; Zhang, Y. Visible light-driven photocatalytically active g- $\mathrm{C}_{3} \mathrm{~N}_{4}$ material for enhanced generation of $\mathrm{H}_{2} \mathrm{O}_{2}$. Appl. Catal. B Environ. 2018, 232, 19-25. [CrossRef]

111. Qu, X.; Hu, S.; Li, P.; Li, Z.; Wang, H.; Ma, H.; Li, W. The effect of embedding $\mathrm{N}$ vacancies into g- $\mathrm{C}_{3} \mathrm{~N}_{4}$ on the photocatalytic $\mathrm{H}_{2} \mathrm{O}_{2}$ production ability via $\mathrm{H}_{2}$ plasma treatment. Diam. Relat. Mater. 2018, 86, 159-166. [CrossRef]

112. Wang, R.; Zhang, X.; Li, F.; Cao, D.; Pu, M.; Han, D.; Yang, J.; Xiang, X. Energy-level dependent $\mathrm{H}_{2} \mathrm{O}_{2}$ production on metal-free, carbon-content tunable carbon nitride photocatalysts. J. Energy Chem. 2018, 27, 343-350. [CrossRef]

113. Moon, G.-H.; Kim, W.; Bokare, A.D.; Sung, N.-E.; Choi, W. Solar production of $\mathrm{H}_{2} \mathrm{O}_{2}$ on reduced graphene oxide- $\mathrm{TiO}_{2}$ hybrid photocatalysts consisting of earth-abundant elements only. Energy Environ. Sci. 2014, 7, 4023-4028. [CrossRef]

114. Kim, H.; Gim, S.; Jeon, T.H.; Kim, H.; Choi, W. Distorted Carbon Nitride Structure with Substituted Benzene Moieties for Enhanced Visible Light Photocatalytic Activities. ACS Appl. Mater. Interfaces 2017, 9, 40360-40368. [CrossRef]

115. Dong, S.; Liu, C.; Chen, Y. Boosting exciton dissociation and molecular oxygen activation by in-plane grafting nitrogen-doped carbon nanosheets to graphitic carbon nitride for enhanced photocatalytic performance. $J$. Colloid Interface Sci. 2019, 553, 59-70. [CrossRef]

116. Wang, H.; Guan, Y.; Hu, S.; Pei, Y.; Ma, W.; Fan, Z. Hydrothermal Synthesis of Band Gap-Tunable Oxygen-Doped g- $\mathrm{C}_{3} \mathrm{~N}_{4}$ with Outstanding "two-Channel" Photocatalytic $\mathrm{H}_{2} \mathrm{O}_{2}$ Production Ability Assisted by Dissolution-Precipitation Process. Nano 2019, 14, 1950023. [CrossRef]

117. Bai, J.; Sun, Y.; Li, M.; Yang, L.; Li, J. The effect of phosphate modification on the photocatalytic $\mathrm{H}_{2} \mathrm{O}_{2}$ production ability of $\mathrm{g}_{-} \mathrm{C}_{3} \mathrm{~N}_{4}$ catalyst prepared via acid-hydrothermal post-treatment. Diam. Relat. Mater. 2018, 87, 1-9. [CrossRef]

118. Zang, L. Interfacial Donor-Acceptor Engineering of Nanofiber Materials To Achieve Photoconductivity and Applications. Acc. Chem. Res. 2015, 48, 2705-2714. [CrossRef]

119. Kofuji, Y.; Isobe, Y.; Shiraishi, Y.; Sakamoto, H.; Tanaka, S.; Ichikawa, S.; Hirai, T. Carbon Nitride-Aromatic Diimide-Graphene Nanohybrids: Metal-Free Photocatalysts for Solar-to-Hydrogen Peroxide Energy Conversion with 0.2\% Efficiency. J. Am. Chem. Soc. 2016, 138, 10019-10025. [CrossRef]

120. Yang, Y.; Zhang, C.; Huang, D.; Zeng, G.; Huang, J.; Lai, C.; Zhou, C.; Wang, W.; Guo, H.; Xue, W.; et al. Boron nitride quantum dots decorated ultrathin porous $\mathrm{g}_{-} \mathrm{C}_{3} \mathrm{~N}_{4}$ : Intensified exciton dissociation and charge transfer for promoting visible-light-driven molecular oxygen activation. Appl. Catal. B Environ. 2019, 245, 87-99. [CrossRef]

121. He, Z.; Kim, C.; Lin, L.; Jeon, T.H.; Lin, S.; Wang, X.; Choi, W. Formation of heterostructures via direct growth $\mathrm{CN}$ on h-BN porous nanosheets for metal-free photocatalysis. Nano Energy 2017, 42, 58-68. [CrossRef]

122. Kofuji, Y.; Isobe, Y.; Shiraishi, Y.; Sakamoto, H.; Ichikawa, S.; Tanaka, S.; Hirai, T. Hydrogen Peroxide Production on a Carbon Nitride-Boron Nitride-Reduced Graphene Oxide Hybrid Photocatalyst under Visible Light. ChemCatChem 2018, 10, 2070-2077. [CrossRef]

123. Wang, H.; Zhang, L.; Chen, Z.; Hu, J.; Li, S.; Wang, Z.; Liu, J.; Wang, X. Semiconductor heterojunction photocatalysts: Design, construction, and photocatalytic performances. Chem. Soc. Rev. 2014, 43, 5234-5244. [CrossRef] [PubMed] 
124. Zheng, Y.; Yu, Z.; Ou, H.; Asiri, A.M.; Chen, Y.; Wang, X. Black Phosphorus and Polymeric Carbon Nitride Heterostructure for Photoinduced Molecular Oxygen Activation. Adv. Funct. Mater. 2018, 28, 1705407. [CrossRef]

125. Li, R.; Li, C. Chapter One-Photocatalytic Water Splitting on Semiconductor-Based Photocatalysts. In Advances in Catalysis; Song, C., Ed.; Academic Press: Cambridge, MA, USA, 2017; Volume 60, pp. 1-57.

126. Chen, Y.-C.; Smirniotis, P. Enhancement of Photocatalytic Degradation of Phenol and Chlorophenols by Ultrasound. Ind. Eng. Chem. Res. 2002, 41, 5958-5965. [CrossRef]

127. Qin, T.; You, Z.; Wang, H.; Shen, Q.; Zhang, F.; Yang, H. Preparation and photocatalytic behavior of carbon-nanodots/graphitic carbon nitride composite photocatalyst. J. Electrochem. Soc. 2017, 164, H211-H214. [CrossRef]

128. Desipio, M.M.; Thorpe, R.; Saha, D. Photocatalytic Decomposition of Paraquat Under Visible Light by Carbon Nitride and Hydrogen Peroxide. Optik 2018, 172, 1047-1056. [CrossRef]

129. Wang, X.; Li, D.; Nan, Z. Effect of $\mathrm{N}$ content in $\mathrm{g}-\mathrm{C}_{3} \mathrm{~N}_{4}$ as metal-free catalyst on $\mathrm{H}_{2} \mathrm{O}_{2}$ decomposition for $\mathrm{MB}$ degradation. Sep. Purif. Technol. 2019, 224, 152-162. [CrossRef]

130. Dinesh, G.K.; Chakma, S. Mechanistic investigation in degradation mechanism of 5-fluorouracil using graphitic carbon nitride. Ultrason. Sonochem. 2019, 50, 311-321. [CrossRef] [PubMed]

131. Teng, Z.; Yang, N.; Lv, H.; Wang, S.; Hu, M.; Wang, C.; Wang, D.; Wang, G. Edge-Functionalized g- $\mathrm{C}_{3} \mathrm{~N}_{4}$ Nanosheets as a Highly Efficient Metal-free Photocatalyst for Safe Drinking Water. Chem 2019, 5, 664-680. [CrossRef]

132. Saha, D.; Desipio, M.M.; Hoinkis, T.J.; Smeltz, E.J.; Thorpe, R.; Hensley, D.K.; Fischer-Drowos, S.G.; Chen, J. Influence of hydrogen peroxide in enhancing photocatalytic activity of carbon nitride under visible light: An insight into reaction intermediates. J. Environ. Chem. Eng. 2018, 6, 4927-4936. [CrossRef]

133. Chen, Q.L.; Liu, Y.L.; Tong, L.G. Enhanced visible light photocatalytic activity of $\mathrm{g}-\mathrm{C}_{3} \mathrm{~N}_{4}$ assisted by hydrogen peroxide. Mater. Res. Express 2018, 5, 046203. [CrossRef]

134. Wu, Q.; He, Y.; Zhang, H.; Feng, Z.; Wu, Y.; Wu, T. Photocatalytic selective oxidation of biomass-derived 5-hydroxymethylfurfural to 2,5-diformylfuran on metal-free $\mathrm{g}-\mathrm{C}_{3} \mathrm{~N}_{4}$ under visible light irradiation. Mol. Catal. 2017, 436, 10-18. [CrossRef]

135. Jiang, L.; Yuan, X.; Zeng, G.; Wu, Z.; Liang, J.; Chen, X.; Leng, L.; Wang, H.; Wang, H. Metal-free efficient photocatalyst for stable visible-light photocatalytic degradation of refractory pollutant. Appl. Catal. B Environ. 2018, 221, 715-725. [CrossRef]

136. Wang, H.; Su, Y.; Zhao, H.; Yu, H.; Chen, S.; Zhang, Y.; Quan, X. Photocatalytic oxidation of aqueous ammonia using atomic single layer graphitic- $\mathrm{C}_{3} \mathrm{~N}_{4}$. Environ. Sci. Technol. 2014, 48, 11984-11990. [CrossRef]

137. Zhang, Q.; Chen, P.; Tan, C.; Chen, T.; Zhuo, M.; Xie, Z.; Wang, F.; Liu, H.; Cai, Z.; Liu, G.; et al. A photocatalytic degradation strategy of PPCPs by a heptazine-based $\mathrm{CN}$ organic polymer (OCN) under visible light. Environ. Sci. Nano 2018, 5, 2325-2336. [CrossRef]

138. Wang, H.; Guo, H.; Zhang, N.; Chen, Z.; Hu, B.; Wang, X. Enhanced Photoreduction of U(VI) on $\mathrm{C}_{3} \mathrm{~N}_{4}$ by $\mathrm{Cr}(\mathrm{VI})$ and Bisphenol A: ESR, XPS, and EXAFS Investigation. Environ. Sci. Technol. 2019, 53, 6454-6461. [CrossRef]

139. Wang, Z.; Murugananthan, M.; Zhang, Y. Graphitic carbon nitride based photocatalysis for redox conversion of arsenic(III) and chromium(VI) in acid aqueous solution. Appl. Catal. B Environ. 2019, 248, 349-356. [CrossRef]

140. Wang, H.; Li, Q.; Zhang, S.; Chen, Z.; Wang, W.; Zhao, G.; Zhuang, L.; Hu, B.; Wang, X. Visible-light-driven $\mathrm{N}_{2}-\mathrm{g}-\mathrm{C}_{3} \mathrm{~N}_{4}$ as a highly stable and efficient photocatalyst for bisphenol A and $\mathrm{Cr}(\mathrm{VI})$ removal in binary systems. Catal. Today 2019, 335, 110-116. [CrossRef]

141. Chen, J.; Xu, X.; Li, T.; Pandiselvi, K.; Wang, J. Toward High Performance 2D/2D Hybrid Photocatalyst by Electrostatic Assembly of Rationally Modified Carbon Nitride on Reduced Graphene Oxide. Sci. Rep. 2016, 6, 37318. [CrossRef]

142. Svoboda, L.; Praus, P.; Lima, M.J.; Sampaio, M.J.; Matýsek, D.; Ritz, M.; Dvorský, R.; Faria, J.L.; Silva, C.G. Graphitic carbon nitride nanosheets as highly efficient photocatalysts for phenol degradation under high-power visible LED irradiation. Mater. Res. Bull. 2018, 100, 322-332. [CrossRef]

143. Yazici, E.; Deveci, H. Factors Affecting Decomposition of Hydrogen Peroxide. In Proceedings of the XIIth International Mineral Processing Symposium, Cappadocia-Nevşehir, Turkey, 6 October 2010; pp. 609-616. 
144. Cheng, F.; Wang, H.; Dong, X. The amphoteric properties of $g-\mathrm{C}_{3} \mathrm{~N}_{4}$ nanosheets and fabrication of their relevant heterostructure photocatalysts by an electrostatic re-assembly route. Chem. Commun. 2015, 51, 7176-7179. [CrossRef] [PubMed]

145. Bicheng, Z.; Xia, P.; Ho, W.; Yu, J. Isoelectric point and adsorption activity of porous g-C $\mathrm{C}_{3} \mathrm{~N}_{4}$. Appl. Surf. Sci. 2015, 344, 188-195.

146. Torres-Pinto, A.; Sampaio, M.J.; Silva, C.G.; Faria, J.L.; Silva, A.M.T. Metal-free carbon nitride photocatalysis with in-situ hydrogen peroxide generation for the degradation of aromatic compounds. Appl. Catal. B Environ. 2019, 252, 128-137. [CrossRef]

147. Hu, J.-Y.; Tian, K.; Jiang, H. Improvement of phenol photodegradation efficiency by a combined g- $\mathrm{C}_{3} \mathrm{~N}_{4}$ /Fe(III)/persulfate system. Chemosphere 2016, 148, 34-40. [CrossRef]

148. Yuan, X.; Xie, R.; Zhang, Q.; Sun, L.; Long, X.; Xia, D. Oxygen functionalized graphitic carbon nitride as an efficient metal-free ozonation catalyst for atrazine removal: Performance and mechanism. Sep. Purif. Technol. 2019, 211, 823-831. [CrossRef]

149. Li, X.; Pi, Y.; Wu, L.; Xia, Q.; Wu, J.; Li, Z.; Xiao, J. Facilitation of the visible light-induced Fenton-like excitation of $\mathrm{H}_{2} \mathrm{O}_{2}$ via heterojunction of $\mathrm{g}-\mathrm{C}_{3} \mathrm{~N}_{4} / \mathrm{NH}_{2}$-Iron terephthalate metal-organic framework for $\mathrm{MB}$ degradation. Appl. Catal. B Environ. 2017, 202, 653-663. [CrossRef]

150. Ren, S.; Chen, C.; Zhou, Y.; Dong, Q.; Ding, $\mathrm{H}$. The $\alpha-\mathrm{Fe}_{2} \mathrm{O}_{3} / \mathrm{g}-\mathrm{C}_{3} \mathrm{~N}_{4}$ composite as an efficient heterogeneous catalyst with combined Fenton and photocatalytic effects. Res. Chem. Intermediat. 2017, 43, 3307-3323. [CrossRef]

151. Desipio, M.M.; Van Bramer, S.E.; Thorpe, R.; Saha, D. Photocatalytic and photo-fenton activity of iron oxide-doped carbon nitride in 3D printed and LED driven photon concentrator. J. Hazard. Mater. 2019, 376, 178-187. [CrossRef] [PubMed]

152. Ding, Q.; Lam, F.L.Y.; $\mathrm{Hu}, \mathrm{X}$. Complete degradation of ciprofloxacin over $\mathrm{g}-\mathrm{C}_{3} \mathrm{~N}_{4}$-iron oxide composite via heterogeneous dark Fenton reaction. J. Environ. Manag. 2019, 244, 23-32. [CrossRef] [PubMed]

153. Pedrosa, M.; Sampaio, M.J.; Horvat, T.; Nunes, O.C.; Dražić, G.; Rodrigues, A.E.; Figueiredo, J.L.; Silva, C.G.; Silva, A.M.T.; Faria, J.L. Visible-light-induced self-cleaning functional fabrics using graphene oxide/carbon nitride materials. Appl. Surf. Sci. 2019, 497, 143757. [CrossRef]

154. Moreira, N.F.F.; Sampaio, M.J.; Ribeiro, A.R.; Silva, C.G.; Faria, J.L.; Silva, A.M.T. Metal-free g- $\mathrm{C}_{3} \mathrm{~N}_{4}$ photocatalysis of organic micropollutants in urban wastewater under visible light. Appl. Catal. B Environ. 2019, 248, 184-192. [CrossRef]

155. Wang, Y.; Li, H.; Yao, J.; Wang, X.; Antonietti, M. Synthesis of boron doped polymeric carbon nitride solids and their use as metal-free catalysts for aliphatic C-H bond oxidation. Chem. Sci. 2011, 2, 446-450. [CrossRef]

156. Min, B.H.; Ansari, M.B.; Mo, Y.H.; Park, S.E. Mesoporous carbon nitride synthesized by nanocasting with urea/formaldehyde and metal-free catalytic oxidation of cyclic olefins. Catal. Today 2013, 204, 156-163. [CrossRef]

157. Lopes, J.C.; Sampaio, M.J.; Fernandes, R.A.; Lima, M.J.; Faria, J.L.; Silva, C.G. Outstanding response of carbon nitride photocatalysts for selective synthesis of aldehydes under UV-LED irradiation. Catal. Today 2019. [CrossRef]

158. Zhang, J.J.; Ge, J.M.; Wang, H.H.; Wei, X.; Li, X.H.; Chen, J.S. Activating Oxygen Molecules over Carbonyl-Modified Graphitic Carbon Nitride: Merging Supramolecular Oxidation with Photocatalysis in a Metal-Free Catalyst for Oxidative Coupling of Amines into Imines. ChemCatChem 2016, 8, 3441-3445. [CrossRef]

(C) 2019 by the authors. Licensee MDPI, Basel, Switzerland. This article is an open access article distributed under the terms and conditions of the Creative Commons Attribution (CC BY) license (http://creativecommons.org/licenses/by/4.0/). 